Marek DMITRUK

(Warszawa, ChAT)

\title{
OBYCZAJE WESELNE I POGRZEBOWE CHRZEŚCIJAN W ŚWIETLE DUSZPASTERSKIEJ DZIAŁALNOŚCI SW. JANA CHRYZOSTOMA
}

Sukcesy Kościoła końca IV wieku wydawały się być niewątpliwe. Zakończono wreszcie ariańskie spory, ustalono terminologię trynitarną, administracja kościelna pokrywała coraz gęstszą siatką tereny Imperium. Sukces doktrynalny i prawny spowodował, że nieco zapomniano o pewnej płaszczyźnie misyjnej działalności Kościoła. Chociaż chrześcijaństwo na przełomie IV i V wieku ostatecznie zawładnęło Cesarstwem, pozostałości dawnych obyczajów były wciąż jeszcze żywe w różnych przejawach życia jego obywateli. Pozorna chrystianizacja życia codziennego stwarzała poważne wyzwanie dla najbardziej przedsiębiorczych duszpasterzy tego okresu. Do czołowych ich przedstawicieli należał niewątpliwie św. Jan Chryzostom (ok. 349-407) - początkowo od 386 r. kapłan w Antiochii, a następnie, od 398 r. biskup stołecznego Konstantynopola. Nieustannie uwidaczniająca się antyteza dwóch światów: chrześcijańskiego i pogańskiego, w znacznym stopniu predestynowała treść duszpasterskich poczynań Jana. Jego posługa sprowadzała się w takim przypadku do nauczania prawd Ewangelii na płaszczyźnie wszelkich przejawów codziennej egzystencji wiernych. Chryzostomowi wydawało się oczywiste, że chrześcijaństwo nie zrealizowane w zwykłym, codziennym życiu, traci swoją autentyczność i zarazem zdolność zmiany otaczającej rzeczywistości. Nie widział on możliwości kompromisu chrześcijaństwa z regułami „tego świata”, które za wszelką cenę starał się transcendować. Kościół w osobie Jana pragnął objąć wpływem całość życia człowieka we wszelkich jego przejawach. Nie wynikało to bynajmniej z jakiegoś egoistycznego pretensjonalizmu. Chryzostom był z powołania nosicielem chrześcijaństwa, pojmowanego w jego apostolskiej czystości i autentyczności. Złożyła się na to przede wszystkim jego ascetyczna formacja. Nie bez znaczenia był również powoli odchodzący w zapomnienie, aczkolwiek konsekwentnie przez niego propagowany, duch bezkompromisowości i zdecydowania, charakteryzujący dobę męczenników. Chryzostom na przełomie IV i V stulecia był już epigonem epoki, która bezpowrotnie odchodząc, sugerowała znalezienie nowych, mniej rygorystycznych duszpasterskich rozwiązań. 
Mając to wszystko na uwadze, nie wydaje się czymś nadzwyczajnym, że nie istniała dziedzina życia, która mogłaby być obca oddziaływaniu tego duszpasterza. Intrygowało go zarówno życie rodzinne, jak również spędzanie czasu na teatralnych i cyrkowych widowiskach; zagrożenie moralności chrześcijańskiej dostrzegał także w niektórych uroczystościach ślubnych i pogrzebowych: nie wahał się w nich bezlitośnie demaskować niewłaściwe zachowania swych duchowych owieczek, ukazując jednocześnie biblijne wzorce prawidłowego postępowania.

Propagowany przez Jana ideał chrześcijanina wyrastał z Pawłowej zachęty do nowego życia w Chrystusie, nakreślonej na kartach Nowego Testamentu. Idea ta wymagała od chrześcijanina całkowitego zaangażowania w sprawy wiary, postulowała zinterioryzowanie odpowiedniego wzorca zachowań, wykraczającego swym zasięgiem znacznie poza próg świątyni. $\mathrm{Z}$ takim modelem chrześcijaństwa, bardzo zresztą ambitnym, jak na koniunkturalną atmosferę pokonstantyńskiego Kościoła, wyraźnie kłóciła się powszechnie wówczas praktykowana helleńska obyczajowość. Aby zrozumieć przyczyny oraz skalę negatywnej reakcji Jana Chryzostoma wobec weselnych oraz pogrzebowych obyczajów chrześcijan, warto chociaż ogólnikowo przyjrzeć się, w jaki sposób pojmował on tak ważne dla każdego człowieka kwestie, jak małżeństwo oraz śmierć.

\section{OBYCZAJE WESELNE}

Św. Jan Chryzostom w swojej duszpasterskiej działalności zwracał szczególną uwagę na wartość małżeństwa, jako ustanowionego przez Boga związku, którego istota wybiega daleko poza ramy doczesności. Stąd nie dziwi jego gwałtowna reakcja na występki i nadużycia, które miały miejsce podczas uroczystości związanych z zawieraniem małżeństw. W obliczu dewaluacji wartości związku małżeńskiego u ówczesnych chrześcijan, z właściwą sobie intuicją kreślił on głęboko osadzony w biblijnej treści soteryczny aspekt małżeństwa ${ }^{1}$.

1. Cele małżeństwa. Skąd się wzięło małżeństwo, jaki był jego cel? Chryzostom udzielając na to odpowiedzi zauważa, że już w Adamie drzemała idea

${ }^{1}$ Myśli Chryzostoma na temat małżeństwa rozsiane są w wielu jego dziełach, szczególnie wáhomiliach egzegetycznych dotyczących Księgi Rodzaju, Ewangelii według św. Mateusza i Ewangelii według św. Jana oraz w 250 homiliach na listy św. Pawła. Złotousty był najlepszym komentatorem Pawłowej myśli w starożytności, a ta, jak wiadomo, dostarcza wielu impulsów do zajęcia się zagadnieniem małżeństwa. Istnieją również trzy homilie Chryzostoma poświęcone w całości temu zagadnieniu, a mianowicie In illud: „Propter fornicationes uxorem”, PG 51, 207-218; De libello repudii, PG 51, 217-226; Quales ducendae sint uxores, PG 51, 225-242. Wreszcie małzeństwu poświęcona jest w całości 20. Homilia na List do Efezjan (PG 62,135-150), uchodząca za najpiękniejszą patrystyczną wykładnię Pawłowej koncepcji małżeństwa. 
kobiety, domagająca się realnego urzeczywistnienia. Po przebudzeniu się bowiem z zesłanego przez Boga snu i zobaczeniu niewiasty, wykrzyknął on radośnie: „Ta dopiero jest kością z kości moich i ciałem z ciała mojego” ( $\mathrm{Rdz} 2$, $22)^{2}$. Już w pierwszej chwili wiedział, że oto ma przed oczyma „tę”, której istnienia tak bardzo pragnął, która stanowić będzie przyczynę jego wielkiej radości ${ }^{3}$.

Jan Chryzostom zwracał uwagę na filologiczną subtelność przekazu biblijnego, opisującego stworzenie niewiasty. Natchniony autor zamiast czasownika

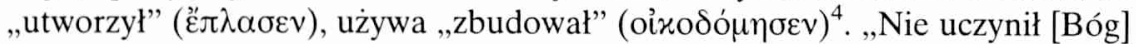
innego stworzenia, lecz wziął z gotowego już małą cząstkę, z której ukształtował cały organizm"5. Egzegeta akcentuje przez to tożsamość natury Adama i niewiasty oraz to, że razem tworzą doskonałą całość. Stwórca wychodząc naprzeciw wielkiemu pragnieniu Adama, powierzył mu kobietę - podobnego jemu pomocnika. Jan podkreślał, że współżycie płciowe i w konsekwencji rodzenie dzieci, nastąpiło dopiero po wygnaniu z raju ${ }^{6}$. Zauważał również, że Pismo św. nie łączy ściśle rodzenia potomstwa $z$ istotą związku małżeńskiego. Wypowiedź Ewy po urodzeniu Kaina $(\mathrm{Rdz} 4,1)$ wskazuje na odrębność procesu rodzenia, jako daru Bożego ${ }^{7}$. Chryzostom, jak widać, nie zaliczal prokreacji do istoty małżeństwa. W czym więc ona się zawiera? Św. Paweł nazywa małżeństwo „wielką tajemnicą", bowiem wskazywał na nie, jako na coś wielkiego i godnego podziwu już Mojżesz, a raczej przez niego sam Bóg ${ }^{8}$. Jan komentując myśl ulubionego Apostoła mówił o jego podziwie i zdumieniu wobec wzniosłości związku małżeńskiego ${ }^{9}$. Podaje również tego przyczynę: małżeństwo nie jest dziełem człowieka ${ }^{10}$.

Małżeństwo jest ustanowione nie dlatego, żeby oddawać się rozpuście i nierządowi, lecz aby człowieka trzymać w czystości i wstrzemięźliwości ${ }^{11}$; zostało ustanowione w dwojakim celu: by zachować ludzi w czystości oraz by uczynić ich rodzicami, lecz z tych dwóch ważniejsza jest czystość ${ }^{12}$. Chrześcijański związek małzeński ma ponadto na celu realizowanie jedności Chrystusa z Kościołem:

${ }^{2}$ Por. In Genesim hom. 15, 3, PG 53, 122C.

${ }^{3}$ Por. tamże.

${ }^{4}$ Por. tamże, 121C

5 Tamże, 122A.

${ }^{6}$ Por. In Genesim hom. 18, 4, PG 53, 153A.

7 Por. tamże, 153C.

${ }^{8}$ Por. In Epistolam ad Ephesios hom. 20, 4, PG 62, 140B. Starożytność chrześcijańska bez zastrzeżeń przypisywała Mojżeszowi autorstwo Pięcioksięgu, Chryzostom nie był tu wyjątkiem.

${ }^{9}$ Por. Quales ducendae sint uxores 3, PG 51, 230BC.

${ }^{10}$ Por. tamże, 230B.

11 Por. In illud: „Propter fornicationes uxorem” 3, PG 51, 212C-213A

${ }^{12}$ Por. tamże, 213A. 
„Podobnie jak nowożeniec (ó vvфíos), zostawiwszy ojca, przychodzi do oblubienicy ( wybranki. [...]. Dlatego też Apostoł powiedział: «tajemnica to wielka» (Ef 5, 32). Jest ona wielka również w stosunku do ludzi; kiedy widzę, że to samo miało miejsce z Chrystusem i Kościołem, wtedy zdumiewam się, wówczas popadam w zdziwienie. Oto dlaczego, [Apostoł] powiedziawszy: «tajemnica to wielka», dodał jeszcze: «a ja odnoszę to do Chrystusa i Kościoła» (Ef 5, 32). Tak więc wiedząc, jak wielkim misterium jest małżeństwo, i jak wielkiego wydarzenia jest ono obrazem, nie sądź o nim zwyczajnie i w sposób przypadkowy [...]"13.

Małżeństwo jest naprawdę wielką tajemnicą, zawierającą w sobie ukrytą mądrość $^{14}$. Nie jest ono bowiem następstwem namiętności czy też żądzy cielesnej, lecz stanowi związek w całej pełni duchowy: w nim dusza jednoczy się z Bogiem w niewypowiedziany sposób, znany jedynie Jemu ${ }^{15}$.

W Homilii XII na List do Kolosan, kaznodzieja sprzeciwia się nieprzyzwoitym obyczajom towarzyszącym uroczystościom weselnym:

„Małżeństwo nie jest widowiskiem. Jest to misterium i obraz wielkiego dzieła. [...]. To obraz Chrystusa i Kościoła, [...], wielka tajemnica, [...], obraz nie czegoś ziemskiego, lecz samego Boga, [...] misterium miłości"16.

Tajemnica małżeństwa zawiera się również w tym, że mężczyzna i kobieta brani osobno, nie tworzą doskonałej całości:

„Każde z nich, traktowane oddzielnie, jest czymś niepełnym, jak gdyby zabrano im jakąś część ciała. Nie są zdolni [w takim stanie] rodzić dzieci, ani uporządkować należycie doczesnego życia. $\mathrm{Z}$ tego właśnie powodu prorok mówi [o kobiecie]: «nadmiar ducha twego» (Ml 2, 15). Mąż i żona stanowią nie dwa ciała, lecz jedno"17.

Owa jedność bierze swój początek już w chwili ukształtowania pierwszej niewiasty: „Stwórcza mądrość Boża od samego początku rozdzieliła jednego [człowieka] na dwoje, pragnąc pokazać, że i po tym podziale powstaje jedno [...]. Albowiem kto nie złączył się [więzami małżeństwa], ten nie przedstawia całości, lecz połowę [...]. Bowiem mąż i żona nie są dwojgiem ludzi, lecz jednym czlowiekiem"18.

Chryzostom zachęcając do skromnego prowadzenia się na weselach, podawał jeszcze inny powód: małżeństwo jest sakramentalnym przedstawieniem Kościoła, obrazem tego, w jaki sposób Chrystus przebywa w swojej Oblubie-

${ }^{13}$ Quales ducendae sint uxores 3, PG 51, 230C.

${ }_{14}$ Por. In Epistolam ad Ephesios hom. 20, 4, PG 62, 140C.

15 Por. tamże, 5, 141C.

${ }^{16}$ In Epistolam ad Colossenses hom. 12, 5, PG 62, 387BC.

17 Tamze, 388A.

18 Tamże, 387C-388A. 
nicy $^{19}$. Związek małżeński odzwierciedla w sposób mistyczny rzeczywistość Kościoła, łączność małżonków wzoruje się na jedności Syna Bożego i Jego Ciała - Kościoła. Stosunek Chrystusa, jako Głowy, do Kościoła będącego Oblubienicą, stanowi idealny wzorzec chrześcijańskich kontaktów małżeńskich. Powinny one stanowić obraz tej miłości, którą Chrystus obdarzył Kościót $^{20}$. Chryzostom wskazując na tę rzeczywistość, nazywał ją konieczną „,miarą miłości” męża wobec żony ${ }^{21}$. Łączność małżonków jest odbiciem ścisłego związku Zbawiciela i Oblubienicy. Pismo św. opisując tę rzeczywistość nie mówi o zamieszkaniu z żoną, lecz o połączeniu z nią; oznacza to doskonałą jedność wypływającą z wielkiej miłości ${ }^{22}$.

Na sakramentalny wymiar wskazuje również, zdaniem Chryzostoma, inna osobliwość małżeństwa:

„Doprawdy, jest to misterium, albowiem człowiek opuszcza tego, który go powołał do życia i wychował oraz tę, która go poczęła i urodziła w boleściach [...], łączy się zaś z tą, której przedtem nie widział, nie mając z nią nic wspólnego, i czci ją ponad wszystkich innych. Doprawdy to misterium" ${ }^{23}$.

Na teandryczną rzeczywistość małżeństwa wskazał już natchniony autor Księgi Rodzaju, św. Paweł zaś ogłosił to teraz i odniósł do Chrystusa i Kościoła $^{24}$. Jako jedność dwojga ludzi, w istocie swej daleko wykracza ono poza widzialną rzeczywistość. Miłość męża i żony jest odzwierciedleniem związku Chrystusa z Kościołem. Małżeństwo nie jest więc tylko wspólnotą życia doczesnego o charakterze statycznym: związek małżeński stanowi wielkie misterium, otwierające zbawienną drogę do prawdziwego, odnowionego człowieczeństwa. Wobec takiego pojmowania małżeństwa przez Chryzostoma, zrozumiała jest jego ostra reakcja na przejętą z helleńskiej tradycji obyczajowość weselną, która w oczywisty sposób godziła w wielkość i świętość chrześcijańskiego małżeństwa. „Znieważany jest dar Boży, korzeń naszego powstania”25. Słowa te stały się mottem do całokształtu duszpasterskiej działalności, zmierzającej do zaszczepienia u wiernych właściwego podejścia do uroczystości weselnych.

${ }^{19}$ Por. tamże, 6, 389A.

${ }^{20}$ Por. In Genesim hom. 56, 1, PG 53, 487C.

21 Por. In Epistolam ad Ephesios hom. 20, 2, PG 62,137A.

${ }^{22}$ Por. tamże, 5, 142C.

${ }^{23}$ Tamże, 4, 140B. W czasach Chryzostoma wybór współmałżonka pozostawał głównie w rękach rodziców. Z dzisiejszego punktu widzenia absurdalna sytuacja, gdy nowożeńcy widzą się po raz pierwszy w dniu ślubu, była wówczas na porządku dziennym.

${ }^{24}$ Por. tamże, 4, 140B.

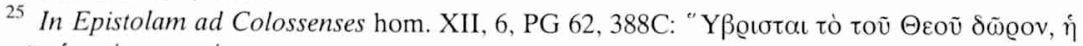

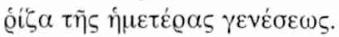


2. Starożytne nieobyczajne zwyczaje weselne. U współczesnych wielkiemu kaznodziei chrześcijan helleńskie obyczaje uzewnętrzniały się najpełniej w weselnych zwyczajach i obrzędach. Zarówno w Antiochii, jak i w stolicy, Chryzostom zdecydowanie występując przeciwko ich niektórym gorszącym praktykom, stanął wobec poważnego duszpasterskiego wyzwania. Kościół od samego początku starał się objąć swoim wpływem sposób zawierania małżeństw, co znajdowało swój wyraz w udzielaniu nowożeńcom błogosławieństwa przez biskupa bądź prezbitera. Pobłogosławiwszy małżeństwo, Kościół nie mógł jednak zabronić zwyczajowych ceremonii, które wskutek wielowiekowej tradycji stanowiły integralny element zawarcia małżeństwa.

W pochodzącej z czasów sprawowania przez Jana biskupstwa 42. Homilii na Dzieje Apostolskie, porównuje on do siebie dwa domy: mieszkańców jednego cechuje powaga, w drugim zaś ma miejsce rozwiązła uroczystość weselna.

„O ile w pierwszym znajdziemy zajmujących się rozważaniem mądrości, o tyle dom

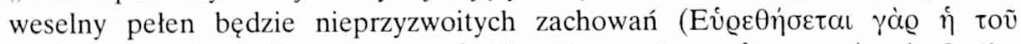

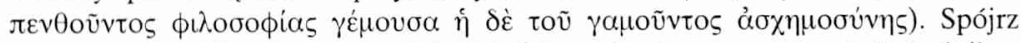

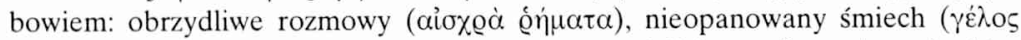

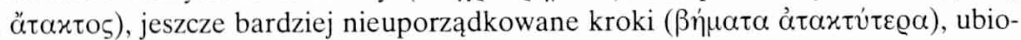

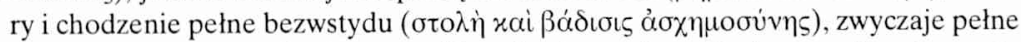

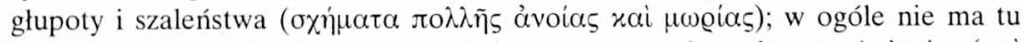
niczego, co nie byłoby bardzo śmieszne, czy też godne wyśmiania (xai

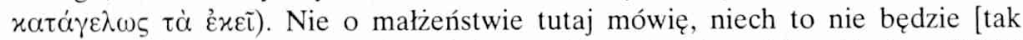
zrozumiane], lecz o tym, co ma miejsce podczas [zawierania] małżeństw ( $\dot{\alpha} \lambda \lambda \dot{\alpha}$

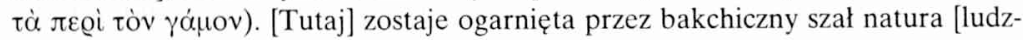

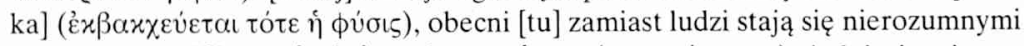

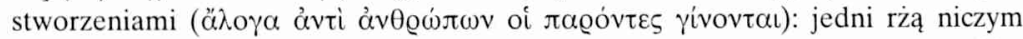
konie, drudzy wierzgają nogami, jak osły, wszystko w zbytku, wszystko w rozkładzie, nic godnego uwagi, nic szlachetnego. Tutaj [jest] wielka uroczystość dla

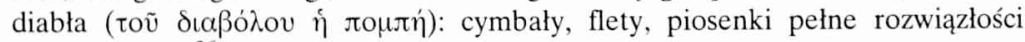
i cudzołóstwa" 26 .

Plastycznie opisana przez Chryzostoma rzeczywistość oddaje, zbliżony do bachanaliów, nastrój panujący na weselu. O ileż bardziej owocna dla cnoty jest powaga, która, jak zauważa Jan, skłania do zajmowania się poszukiwaniem mądrości. Z drugiej strony wszechobecna na weselnej uroczystości powierzchowna wesołość, powoduje uzewnętrznianie się zachowań nie mieszczących się w sferze właściwej dla rozumnego stworzenia, którym przecież jest człowiek.

Niezwykle interesująca pod względem opisywanych obyczajów chrześci$j^{27}{ }^{27}$ jest również 12 Homilia na I List do Koryntian.

26 In Acta Apostolorum hom. 42, 3-4, PG 60, 300C-301A.

27 Obok zwyczajów weselnych Chryzostom piętnuje pogańskie zwyczaje dotyczące nadawania imienia dziecku, a także wróżby i „zamawianie” w celu zapewnienia mu długowieczności 
„Małżeństwo uważane jest za dzieło godne uszanowania zarówno u nas, jak też

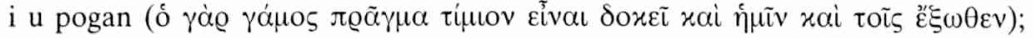
i w rzeczywistości jest ono zaszczytne, lecz podczas zawierania małzeństw czyni się wiele rzeczy śmiesznych, jak o tym zaraz usłyszycie. Wielu naśladując zwyczaj

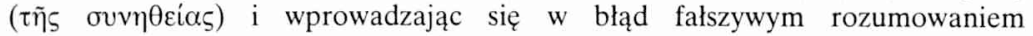
( $\pi \alpha \varrho \alpha \lambda \circ \gamma \iota \zeta o ́ \mu \varepsilon v o \iota)$, nawet nie rozpoznaje niedorzeczności tego wszystkiego i próbuje jeszcze szukać pouczeń od innych. Są tu [na weselach] tańce i cymbały, flety i bezwstydne mowy, niegodziwe piosenki, pijaństwo, nieprzystojne żarty i wszelkie

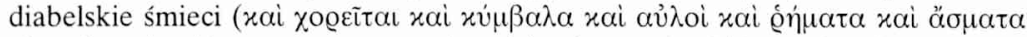

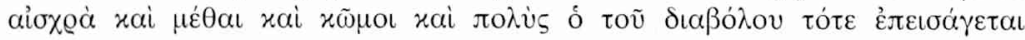
фọvtós). Wiem, że mogę wydać się śmieszny, gdy je potępiam. Mogę też, zmieniając stare prawa ( głupca (ảvoiav), lecz nie patrząc na to, nie przestanę o tym mówić" 28 .

O tym, że przywiązanie wiernych do dawnych zwyczajów nie stanowiło dla duszpasterza bynajmniej błahego problemu, świadczą rozterki autora homilii. Chryzostom ma nadzieję, że chociaż nieliczni go wysłuchają i raczej zgodzą się na to, aby zostać wyśmianymi razem $z$ nim, niż uczestniczyć w tym nierozumnym śmiechu adwersarzy, który, zdaniem Jana, w rzeczywistości wart był raczej łez, nagany i kary ${ }^{29}$.

Jan ubolewał też nad tym, że dziewczyna wychowywana do dnia ślubu w skromności i czystości, podczas weselnych uroczystości obraca się w towarzystwie rozpustników, cudzołożników, ludzi pozbawionych czci i moralnych wartości. Przebywanie w ich obecności rodziło u panny młodej zuchwałość, bezwstyd i próżną chwałę, co na przyszłość zmniejszało jej walory jako kobiety i żony ${ }^{30}$. Czy zwyczaj mógł stanowić ostateczną, ,instancję”, gdy w rachubę wchodziło właściwe pojmowanie chrześcijańskiego małżeństwa? Chryzostom odpowiadał przecząco:

„Nie mów mi o zwyczaju. Jeżeli jest on czymś złym, to niechaj się go ani razu nie przestrzega, jeśli zaś czymś dobrym, niech panuje zawsze" ${ }^{31}$.

Jan zapewne spotykał się niekiedy z zarzutami, że poprzez postulowaną przez siebie moralną surowość, walczył z małżeństwem jako takim. Na tego typu obwinienia Jan odpowiadał, że nie przeciwstawia się małżeństwu, ale walczy

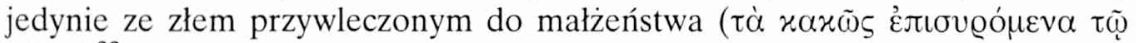
$\gamma \alpha \dot{\mu} \omega)^{32}$.

i szczęścia. Duszpasterza irytował szczególnie lęk ówczesnych chrześcijan przed uczynieniem dziecku krzywdy za pomocą ,złych spojrzeń”, czy zwyczajnej zawiści, zob. In Epistolam I ad Corinthios hom. 12, 7, PG 61, 105BC-106.

${ }^{28}$ In Epistolam I ad Corinthios hom. 12, 5, PG 61, 103B.

${ }^{29}$ Por. tamże, 5, 103BC.

${ }^{30}$ Por. tamże, 5, 103C.

31 Tamze, 5, 103C.

32 Por, tamże, 103C. 
Jak wyglądał dalszy ciąg uroczystości? Otóż goście weselni zajmowali się pijaństwem nie tylko za dnia, lecz również wieczorem ${ }^{33}$. Impreza planowo wymykała się spod kontroli organizatorów biesiady i swym zasięgiem obejmo-

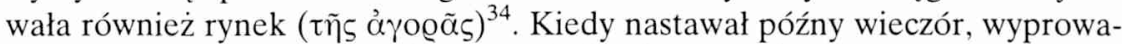

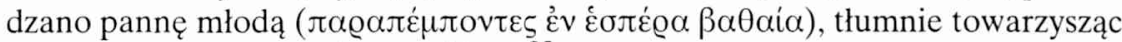
jej z pochodniami ( $\mu \varepsilon \tau \dot{\alpha} \lambda \alpha \mu \tau \alpha \dot{\delta} \omega \nu)^{35}$. Jakby tego było jeszcze mało, jak zauważał ze smutkiem Jan, przeprowadzaniu dziewczyny towarzyszyły obelżywe

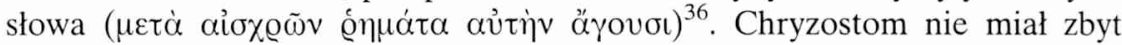
dobrego mniemania o weselnikach, uczestniczących w tego rodzaju proce-

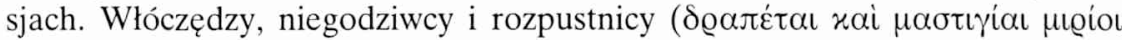

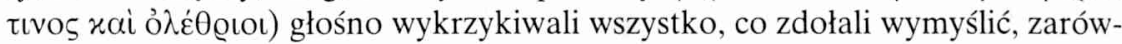
no wobec pana młodego, jak też jego wybranki. Miały miejsca swoiste rywalizacje w tym, kto zwycięży pozostałych w wulgarnym krasomówstwie. Zwycię-

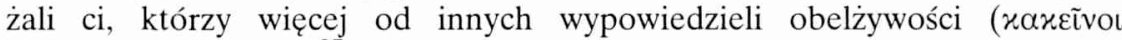

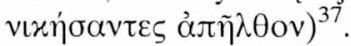

Słuchacze Jana nie dostrzegali niczego niestosownego w praktykowaniu powszechnie uznawanych zwyczajów:

„Lecz, powiesz, taki jest zwyczaj ( $\sigma u v \theta \varepsilon i ̃ \alpha)$. Diabeł wiedząc, że małżeństwo jest

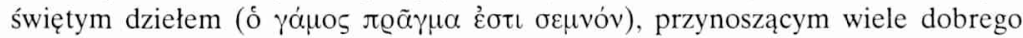

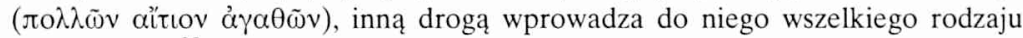
cudzołóstwo" ${ }^{38}$.

Chryzostom zastanawiał się nad celem zakrojonej na tak dużą skalę i prowadzonej z takim rozmachem procesji weselnej:

„Co ma znaczyć to wielkie zgromadzenie? Co to za pijaństwo? Co to za flety? Czyż nie jest oczywiste, że wszystko to służy temu, aby ci, co [w tym czasie] znajdują się w domach i pogrążeni są w głębokim śnie, przebudzili się, dowiedzieli się o tym

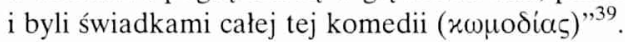

Procesje ślubne potrafiły bowiem obudzić w środku nocy nawet całe miasto, ponieważ do korowodu przyłączali się ludzie z marginesu społecznego, żądni darmowego pijaństwa i zabawy, co dodatkowo potęgowało zamieszanie. O czym zaś śpiewano podczas tych uroczystych procesji?

„A cóż powiedzieć o samych pieśniach, pełnych wszelkiego wyuzdania (ai jáơৎ

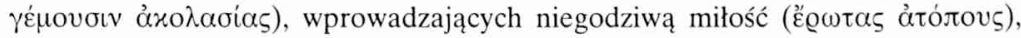

${ }^{33}$ Por. tamże, 6, 104B.

${ }^{34}$ Por. tamże, 6, 104B.

35 Por. tamże, 6, 104B.

${ }^{36}$ Por. tamże, 6, 104B.

37 Por. tamże, 6, 104B.

38 Tamże, 6, 104C.

39 Tamże, 6, 104C-105A. 


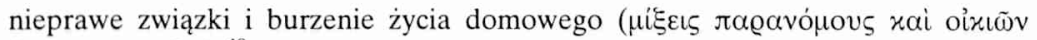

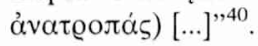

Jan występował zdecydowanie przeciwko podobnemu zachowaniu. Nie potępiał on bynajmniej przejawów radości, związanych z tak ważnym w życiu człowieka wydarzeniem, jak zawarcie małżeństwa, ale jaskrawe nadużycia w tej dziedzinie zmuszały go do ukazywania wiernym właściwych norm postępowania i należnej miary.

Prawdziwy upust swojemu rozgoryczeniu z powodu praktykowania przez powierzonych mu chrześcijan pogańskich zwyczajów weselnych, daje Chryzostom w 56 Homilii na Księgę Rodzaju ${ }^{41}$ :

„Posłuchajcie wy, którzy macie zamiłowanie w szatańskich zabawach (oi $\pi \varepsilon @ i ~ \tau \dot{\alpha} \varsigma$

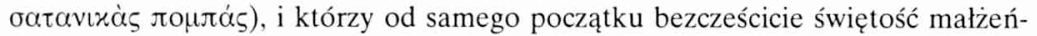

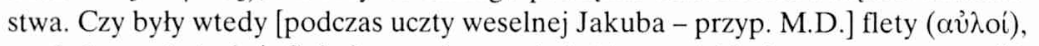

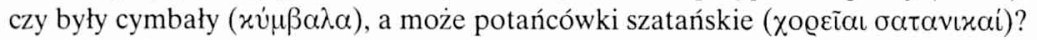
Powiedz mi: dlaczego wprowadzasz wówczas do swego domu wstyd oraz aktorów i tancerzy? (xai toù

Chryzostom przedstawia dalej niebezpieczeństwa, które niesie ze sobą tego typu postępowanie: obraza czystości dziewczyny, otworzenie drogi bezwstydnemu postępowaniu młodzieńca. Młodość podatna jest bowiem na pokusy, a cóż dopiero mówić o takich, jak wspomniane wyżej, sytuacjach. Obecność na weselu ludzi związanych z rozrywką, tańczących i wykonujących wyuzdane gesty, stanowiło, zdaniem Chryzostoma, poważne niebezpieczeństwo dla młodych małżonków. Chłopak mógł zapałać uczuciem do którejś z zaproszonych frywolnych panien, panna młoda zaś obserwując cały spektakl mogłaby wzniecić w sobie trwałą namiętność do obserwowania tego typu przedstawień w przyszłości ${ }^{43}$.
„Dlatego błagam was: przewidziawszy to wszystko, nie idźcie za przyjętym zwy- czajem. Wiem, że wielu powołując się na te zwyczaje, nie chce nawet słuchać naszych słów; nie patrząc jednak na to, jesteśmy zobowiązani do powiedzenia wam tego, co jest pożyteczne i co może uchronić was od mających nastąpić kar. Gdzie ma miejsce aż tak wielka szkoda dla duszy, w jakim celu wskazujesz mi jeszcze na ten zwyczaj?" 4 .

Aby dodatkowo zachęcić wiernych do zmiany postępowania, Jan sięga do ambicji słuchaczy, wskazując na przykład Labana, który będąc bałwochwalcą i nie mając pojęcia o prawdziwej pobożności, gdy wydawał córkę za mąż,

\footnotetext{
40 Tamże, 6, 105A.

${ }^{41}$ Por. In Genesim hom. 56, PG 53, 486C-494C.

42 Tamże, 1, PG 53, 486C.

43 Por, tamże, $487 \mathrm{~A}$.

44 Tamże, 487B.
} 
wykazał odpowiadającą sytuacji mądrość. Widać stąd, że również rodzice nowożeńców mogą mieć znaczący udział w konstruowaniu właściwego wizerunku weselnych uroczystości ${ }^{45}$. Apel Chryzostoma nawiązuje również do myśli jego ulubionego apostoła:

„Czy nie słyszysz słów Pawła, że małżeństwo stanowi misterium - jest obrazem tej miłości, którą Chrystus pokazał w Kościele (por. Ef 5,32) [...]. Jeśli cokolwiek zostało wymyślone dobrze i z pożytkiem, to chociażby nie było takiego zwyczaju, niechaj będzie czynione. Jeśli zaś to, co robicie, jest niepożyteczne i zgubne, chociaż wskazywałby na to zwyczaj, trzeba odrzucić. Przecież, gdybyśmy do tego dopuścili, wtedy zarówno złodziej, rozpustnik i każdy inny złoczyńca będą zasła-

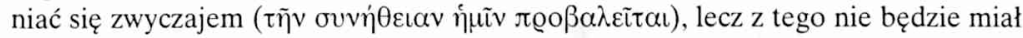
żadnego pożytku, ani [pretekstu do] wybaczenia, ale będzie ciężko osądzony za to, że nie mógł przezwyciężyć złego zwyczaju"46.

Sytuacja była jednak bardziej złożona: słuchacze Chryzostoma zdawali się uważać, iż bez odbycia hucznej, tradycyjnej imprezy, nowo zawiązane małżeństwo będzie czymś niepełnym:

„Nie mówcie mi przy tym pustych i śmiesznych słów, jakoby było to czymś ustanowionym przez prawo, i dlatego powinno być przestrzegane. Nie to czyni praw-

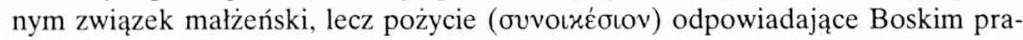
wom, godne czci i skromne, kiedy żyjący ze sobą zjednoczeni są zgodnością. Tak pojmuje to również prawo [państwowe]; zapytaj ludzi zajmujących się jego zgłębianiem, a odpowiedzą ci, że o małżeństwie stanowi nie co innego, jak bliskość albo przyjaźń. Nie występujmy przeciwko prawom Bożym oraz ludzkim, i nie

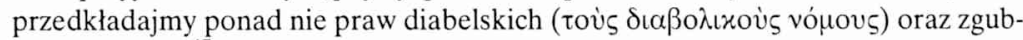
nego byczaju" ${ }^{47}$.

Podsumowując rozważania Jana na temat treści 56. Homilii na Księgę Rodzaju, łatwo zauważyć, że w szczególności irytowała kaznodzieję obecność na weselach postaci związanych z ówczesnym teatrem. Mieli oni zadanie rozweselania gości przy pomocy zmysłowych tańców, żartów i piosenek. Bogate rodziny uważały zaproszenie ich za punkt swego honoru. Było to szczególnie żenujące, albowiem wykraczało daleko poza praktykowane na co dzień normy moralności.

Ostatnia z cyklu interesujących nas homilii - to 12 Homilia na List do Kolosan, w dużej mierze poświęcona również duszpasterskiej polemice z niestosownymi obyczajami na weselach. Chryzostom był oburzony faktem, że na ucztach weselnych obecne były nierządnice ( $\alpha i$ jógval), które zapraszano w celu rozweselania gości. Aby zadośćuczynić pragnieniu wiernych do wprowadzenia na weselach radośniejszej atmosfery, a jednocześnie w celu zapobie-

\footnotetext{
45 Por. tamże, 487BC.

46 Tamże, 487C-488A.

47 Tamże, 2, 488A.
} 
żenia obecności kobiet o wątpliwej reputacji, Chryzostom zezwalał nawet na przygotowanie suto zastawionego stołu i włożenie zbytkownych ubrań: „Nie zabraniam tego, aby nie okazać się zbytnio surowym" "48. Znając jednak duchowość Antiocheńczyka wiadomo, że było to dla niego naprawdę poważne sprzeniewierzenie się własnym ideałom.

Chryzostom wspomina również o ciekawym obyczaju dotyczącym zmiany społecznego statusu przyszłej panny młodej:

„Według mnie dobrze jest, że przychodzą panny, aby uczcić swoją rówieśniczkę; przychodzą również mężatki, aby złożyć wyrazy szacunku tej, która wstępuje do ich społeczności. To dobry zwyczaj. Są tu dwa kółka: jedno składa się z panien, drugie z mężatek; tamte oddają, te przyjmują. Panna młoda pośród nich - nie panienka i [jeszcze] nie mężatka. Stamtąd [z grupy panien] wychodzi, tu zaś wstępuje" ${ }^{\text {49. }}$.

Sytuacja, która miała miejsce podczas weselnych uroczystości, nie miała nic wspólnego z zaleceniami św. Pawła. Chryzostom ubolewal nad tym, że o ile apostoł zabronił, aby z ust chrześcijanina wychodziły jakiekolwiek bezwstydne słowa, błazeńska mowa i nieprzyzwoite żarty (por. Ef 5, 4), to akurat wszystko to występowało w nadmiarze na weselach. Mało tego - wszystko to stało się wyszukaną sztuką, która dostarczała wielkiej chwały tym, którzy się nią zajmo-

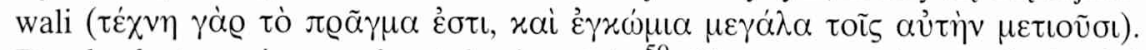
Doszło do tego, że grzechy stały się sztuką ${ }^{50}$. Chryzostoma irytował również inny trwały komponent weselnych uroczystości:

„Lecz jeśli zapewniasz, że nie będą tańczyć dziewczyny ani kobiety, to kto wtedy będzie tańczył? Nikt; nie ma bowiem żadnej konieczności tańców na weselu.

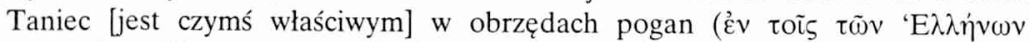

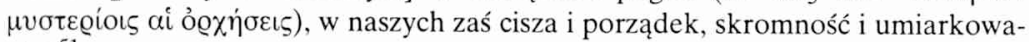
nie" $" 51$.

Wydaje się, że tak surowa opinia Jana wynikała z reakcji na znaczenie tańca w życiu rozrywkowym. Z drugiej strony Chryzostom konsekwentnie zbywał milczeniem obecność „,pobożnego”, pełnego radości Bożej tańca w Starym Testamencie, który często służył mu za natchnienie przy konstruowaniu moralnych rozwiązań.

W jaki sposób Chryzostom starał się uczynić sytuację na weselach chrześcijan bardziej zbliżoną do głoszonych przez niego prawd? Odnośnie do sposobu zawierania związków małżeńskich odwoływał się tu często do postępowania

\footnotetext{
48 In Epistolam ad Colossenses hom. 12, 4, PG 62, 386B.

49 Tamże, 386C.

${ }^{50}$ Por. tamże, 6, 389C.

51 Tamże, 5, 387C.
} 
starotestamentalnych patriarchów. Rzeczywistość współczesna Chryzostomowi miała jednak niewiele wspólnego z biblijnymi ideałami:

„Powiedz mi, z jakiego powodu już od samego początku [związku małżeńskiego] pozwalasz słuchać dziewczynie bezwstydnych pieśni i niestosownych odgłosów? Czyż nie wiesz, jak bardzo młodość podatna jest na zgorszenia? Dlaczego niweczysz godne czci misterium małżeństwa? Wszystko to należy precz odrzucić, i od samego początku nauczać dziewczynę wstydliwości. Należy zaprosić kapłanów

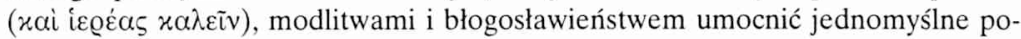
życie $[\ldots], 52$.

Chryzostom mówił o kapłańskim błogosławieństwie związku małżeńskiego, jako rękojmi zgodnego pożycia małżonków.

Recepta na wyleczenie wiernych od dawnych przyzwyczajeń zawierała się więc w realiach Pisma św. oraz w już stosowanej praktyce kościelnej:

„Nie będziemy więc bezcześcić go [wesela] diabelskimi uroczystościami, lecz, tak jak postąpili mieszkańcy Kany Galilejskiej, niechaj czynią i ci, którzy obecnie zawierają małżeństwo: niechaj posiadają pośród siebie Chrystusa. Ale w jaki spo-

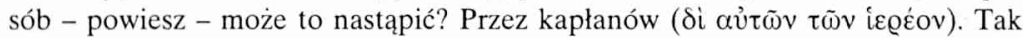
więc, jeśli przepędzisz szatana, odsuniesz rozpustne pieśni, rozwiązłe przyśpiewki,

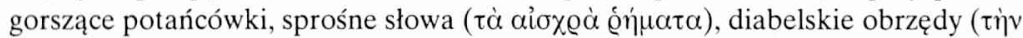

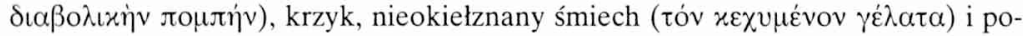
zostałe niegodziwości ( $\alpha$ $\chi \eta \mu \sigma u ́ v \varepsilon v)$, a wprowadzisz świętych [kapłanów] Chrystusa, to doprawdy dzięki nim będzie obecny wśród was Chrystus ze swoją matką i braćmi. [...]. Wiem, że niektórym wydaję się być kimś uciążliwym i nieznośnym, nauczając o tym i niszcząc dawny zwyczaj ( $\pi \alpha \lambda$ aı่̀ mówi, ze taki jest zwyczaj; gdzie dokonuje się grzech, tam nie wspominaj [mi] o zwyczaju, lecz jeśli dokonywane jest zło, to choćby i zwyczaj był dawny, porzuć go, jeśli zaś coś nie jest złe, to choćby i nie było takiego zwyczaju, wprowadź go i zaszczep. A że takie niegodziwości nie tworzą dawnego zwyczaju, lecz jedynie pewne zniekształcenia, przypomnij, jak Izaak wstępował w związek malżeński z Rebeką, i jak Jakub - z Rachelą. Pismo św. wspomina o tych weselach [...], lecz nie wspomina o czymś takim [co ma miejsce u was]; ustanawiali oni biesiadę i obiad lepszy od zwykłego, zapraszali bliskich na wesele, lecz nie było tam fletów, piszczałek, cymbałów, ani nieokiełznanych pląsów, ani pozostałych obecnych dziś nieprzyzwoitości" ${ }^{33}$.

\section{Rzeczywistość była jednak daleka od pobożnych życzeń Jana:}

„A w naszych czasach śpiewa się pieśni z potańcówkami ku czci Afrodyty, opiewając cudzołóstwo, zrywanie małżeństwa, nieprawą miłość, związki kazirodcze, i wiele innych śpiewają w ten dzień [wesela] pieśni, pełnych niegodziwości i bez-

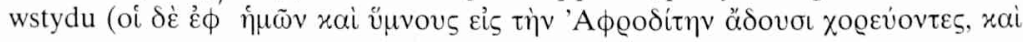

52 In Genesim hom. 48, 6, PG 53, 443C.

53 In illud: „Propter fornicationes uxorem” 2, PG 51, 210BC-211A. 


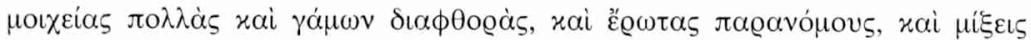

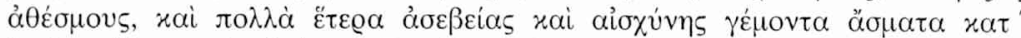

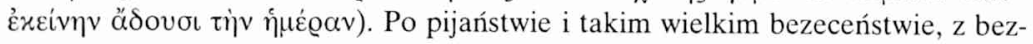
wstydnymi słowami na ustach przy wszystkich wyprowadzana jest dziewczyna $(\hat{\eta}$ vú $\phi \eta)$. Jakim sposobem - powiedz mi - wymagasz od niej czystości, od pierwszego dnia małżeństwa przyuczając ją do takiego bezwstydu [...]. [...]Kiedy wprowadzasz do swego domu błaznów i rozpustników oraz inicjujesz cały spektakl, kiedy napełniasz dom prostytutkami i urządzasz u siebie gościnę dla całego mnóstwa diabłów, to czego - powiedz mi - oczekujesz dobrego? W jakim celu zapra-

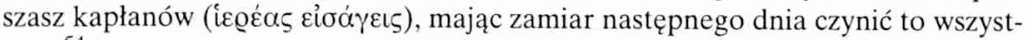
ko? ${ }^{, 54}$.

Świadectwo Chryzostoma wskazuje na powszechność praktyki udzielania związkom małżeńskim kościelnego błogosławieństwa. Jan demaskował moralną sprzeczność i niespójność w pojmowaniu przez jego wiernych małżeństwa: obecność zaproszonych ludzi z branży rozrywkowej stanowiła zniewagę dla kościelnego uświęcenia małżeńskiego związku. Duszpasterz zauważał ponadto, że gdyby nawet żadna kara Boża nie zagrażała podobnie postępującym, należałoby porzucić tego typu zwyczaje przez wzgląd na nowożeńców, którzy podczas wesela skazani są na znoszenie wulgarnych słów wypowiadanych przez pijanych gości ${ }^{55}$.

Współcześni Chryzostomowi chrześcijanie byli bardzo przywiązani do starych zwyczajów weselnych, uświęconych długą ludową tradycją. Na mocy głęboko zakorzenionego przyzwyczajenia, nie byli w stanie wyobrazić sobie wesela bez całej jego zmysłowej otoczki. Nowożeńcy nie uwierzyliby, że są mał-

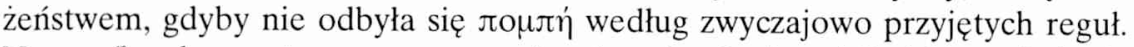
Na prośby duszpasterza o porzucenie niegodnych chrześcijańskiego imienia obyczajów, wierni powoływali się na uświęcony długotrwałym funkcjonowa-

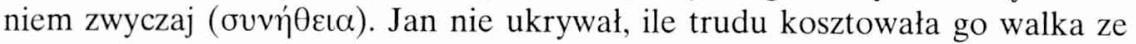
zwyczajami weselnymi; doznał z tego powodu wielu zniewag i nieprzyjemności $^{56}$. Liczni, jak wyznaje, czynili z niego pośmiewisko, zarzucając mu zbytnią surowość $^{57}$. Złotousty jednak, świadomy ewangelicznych wymagań, śmiało nakłaniał powierzonych mu chrześcijan do prawego postępowania i życia według wiary. Nadrzędnym prawem była dla niego Ewangelia; chrześcijański autentyzm wymagał podporządkowania jej wymogom zwyczajowych praw ludzkich.

54 Tamże, 211AB.

55 Por. tamże, 3, 212B.

56 Jedna $\mathrm{z}$ najważniejszych $\mathrm{z}$ homilii na ten temat - Homilia 12 na List do Kolosan, została wygłoszona ok. 399 r. w Konstantynopolu. Świadczy to o fakcie, że pod względem obyczajowości sytuacja w stolicy nie była wcale lepsza, niż w ,barbarzyńskiej” Antiochii.

${ }^{57}$ Por. In Epistolam ad Colossenses hom. 12, 6, PG 62, 389B. 


\section{ZWYCZAJE POGRZEBOWE}

Śmierć bliskiej osoby stanowi dla chrześcijanina prawdziwą próbę wiary. Właśnie rodzaj postawy wobec śmierci najpełniej świadczy o chrześcijańskiej wierze w zmartwychwstanie, o interioryzacji prawdy o zwycięstwie Chrystusa nad śmiercią. Cały Nowy Testament głosi zwycięstwo życia nad śmiercią. Nadmierny smutek z powodu odejścia bliskich od samego początku funkcjonowania Kościoła uchodził za niezdrową i nieuzasadnioną postawę. Jan również nie mógł respektować jaskrawych nadużyć i wynaturzeń przejawianych w kwestiach śmierci i pogrzebu.

1. Chrześcijańska postawa wobec śmierci. Jak wyglądała dogmatyczna świadomość chrześcijan odnośnie zmartwychwstania w czasach Chryzostoma? Czy prawda o powstaniu z martwych była dla „owieczek” Jana czymś oczywistym? W 17. Homilii na I List do Koryntian przedstawił on dowody na możliwość zmartwychwstania ciał. Swoje przykłady czerpał on $\mathrm{z}$ procesów zachodzących w świecie przyrody ${ }^{58}$. Twierdził przy tym, że o kwestii zmartwychwstania ciał mówi jedynie do pogan ( $\pi \varrho o ̀ \varsigma ~ " E \lambda \lambda \eta v a \varsigma)$, bo do tych, któ-

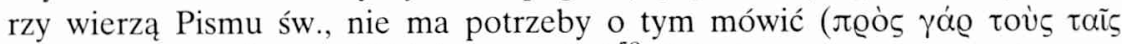

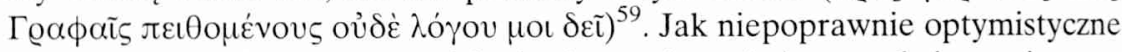
były to słowa, Chryzostom miał okazję przekonać się w trakcie swej pracy duszpasterskiej w stołecznym Konstantynopolu ${ }^{60}$. Nie należy się dziwić wielkiemu znaczeniu, jakie przywiązywali współcześni mu chrześcijanie do zwyczajów pogrzebowych, skoro według jego relacji, mieli oni poważne wątpliwości odnośnie zmartwychwstania ciał ${ }^{61}$. Jan wyraźnie zaświadcza, że nie chodziło mu o pogan. Z nimi rozmowa toczyłaby się wokół takich zagadnień, jak wędrówka dusz, czy też atomowa struktura świata, co dla autora homilii było czymś zupełnie obcym ${ }^{62}$. „Lecz my nie do nich się zwracamy z naszą mową, lecz do wiernych, jeżeli tylko wiernymi można nazwać pytających [o prawdziwość zmartwychwstania ciał - przyp. M.D.]"63. Tych zaś nurtowały pytania w rodzaju: w jaki sposób może ożyć człowiek, który zginął w wyniku morskiej katastrofy, a jego zwłoki zostały pożarte przez mnóstwo ryb; mało tego: owe ryby zostały złowione i zjedzone przez rozmaitych ludzi, ci z kolei zmarli w różnych krajach, na dodatek też zostali zjedzeni przez zwierzęta ${ }^{64}$. Wypada jedynie

${ }^{58}$ Por. In Epistolam I ad I Corinthios hom. 17, 2-3, PG 61, 141-143.

${ }^{59}$ Por. tamże, 3, 142C.

${ }^{60}$ Powstanie Homilii na I List do Koryntian przypada na rok 392 lub 393, a więc na najświetniejsze lata jego kapłańskiej działalności w Antiochii, zaś wykorzystywane później w tekście Homilie na I List do Tesaloniczan zostały napisane ok. $401 \mathrm{r}$. w Konstantynopolu.

61 Por. In Epistolam I ad Thessalonicenses hom. 7, 2, PG 62, 436BC-437A.

${ }^{62}$ Por. tamże, 436C-437A.

63 Tamże, 437A. 
podziwiać duszpasterską rozwagę Chryzostoma wobec tak wielkiej teologicznej „dociekliwości” jego „owieczek”.

O przyczynie nadmiernego żalu po odejściu bliskich pisał Chryzostom na początku 7. Homilii na I List do Tesaloniczan:

„Wiele spraw pogrąża nas w smutku tylko dlatego, że ich nie znamy; kiedy zaś już dobrze zaznajomimy się z nimi - odrzucamy smutek. Wskazując na to, Paweł mówił: «Nie chcemy zaś, bracia, abyście nie wiedzieli o zasypiających, abyście się nie smucili, jak ci pozostali, nie mający nadziei» (1 Tes 4, 13). [...] On [Pawel - przyp. M.D.] mówi do nich w ten sposób nie dlatego, że ci nie wierzyli w zmartwychwstanie, lecz że, nie patrząc na wiarę w nie, opłakiwali [zmarłych - przyp. M.D]"65.

Kontynuując swoje rozważania, pisał dalej:

„Przy tym, dlaczego powiedzial: «jak ci pozostali, nie mający nadziei»? [Paweł] zdawał się rozważać w ten sposób: kogo wy, ludzie, opłakujecie, po kim jesteście pogrążeni w smutku - po grzesznikach, czy w ogóle po umierających? Ci [nie mający nadziei - przyp. M.D.] opłakują [zmarłych], dlatego że wszyscy zmarli są dla nich nikim. «Pierworodny», powiada [Paweł], «Z umarlych» (Kol 1, 18), to znaczy: początek. Tak więc powinni być i inni" ${ }^{66}$.

Rękojmią zmartwychwstania dla każdego chrześcijanina jest sam Chrystus, który jako Syn Boży pokonał śmierć. Przechodząc następnie do analizy treści kolejnego wersetu (1Tes 4,14), Chryzostom wskazywał na precyzję językową św. Pawła:

„«I Bóg», powiada, «tych, którzy zasnęli w Chrystusie, przyprowadzi z nim». Znów

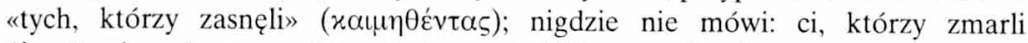

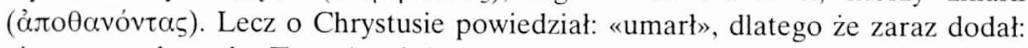
«i zmartwychwstał». Tu zaś: «ci, którzy zasnęli w Chrystusie», rozumie się albo tych, którzy zasnęli w wierze Jezusowej, albo to, że przez Jezusa [Bóg] przywiedzie tych, co zasnęli, to znaczy wiernych.[... $]^{1,67}$.

Chryzostom dostrzegając niebezpieczeństwo w niewłaściwej postawie swoich wiernych względem śmierci, próbował zmienić niepokojący stan biblijnej ignorancji swych owieczek. Aby dodatkowo zdopingować zmianę ich systemu wartości, chwytał się niekiedy środków o charakterze parenetycznym:

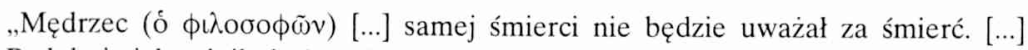
Podobnie jak rolnik, który widząc rozkładające się ziarno, nie popada w rozpacz, a wręcz przeciwnie - dopiero wtedy prawdziwie zachwyca się i raduje wiedząc, że

\footnotetext{
${ }^{64}$ Por. tamże, 436BC.

${ }^{65}$ Tamże, 1, PG 62, 435A.

66 Tamże, 435B.

67 Tamże, 435C-436A.
} 
ów rozkład ziarna bywa początkiem nowego życia. Tak też i sprawiedliwy (ỏ ঠíxaıs) patrząc na śmierć wie, że dla ludzi prawych śmierć stanowi przejście ku

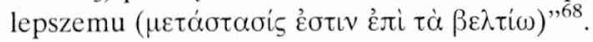

Szczególnie godne uwagi, z punktu widzenia nauki o zmartwychwstaniu, są rozważania Jana o istocie ludzkiego ciała. Chryzostom zauważał, że owo zepsucie ciała, które ma miejsce po śmierci, nie jest zniszczeniem jego istoty, a jedynie zużyciem jego śmiertelności, wyczerpaniem jego znikomości (rai

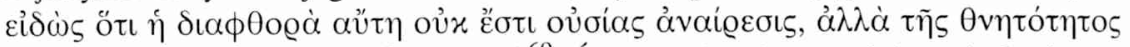

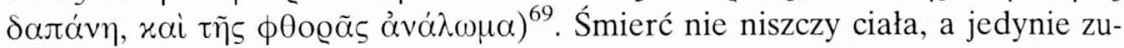
żywa jego zniszczalność, istota zaś pozostaje na zawsze, aby zmartwychwstać

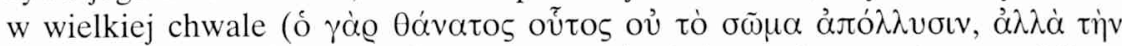

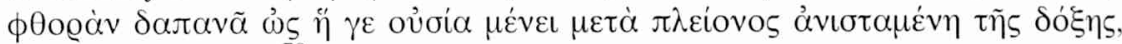

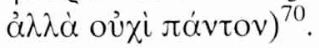

Zagadnienie zmartwychwstania ciał zajmowało czołową pozycję w rozważaniach Zlotoustego zawartych w niewielkiej rozprawie $O$ zmartwychwstaniu umarłych $^{71}$. Na wstępie zastrzegl, że przedmiotem jego rozważań będą nie

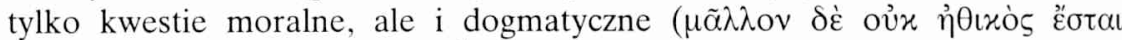

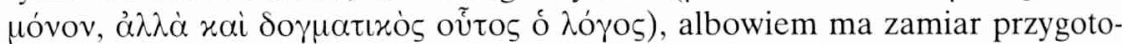

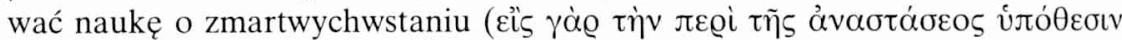

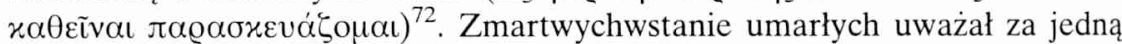
z kluczowych prawd wiary chrześcijańskiej. Chryzostom nawiązując do wypowiedzi apostoła Pawła (2Kor 4,17-18): „Albowiem nieznaczny chwilowy ucisk przynosi nam przeogromną obfitość wiekuistej chwały. Nam, którzy nie patrzymy na to, co widzialne, ale na to, co niewidzialne; albowiem to, co widzialne, jest doczesne, a to, co niewidzialne, jest wieczne" pisał:

„Wyjaśniwszy nam wszystko, dlaczego obecne nazwał doczesnym, przyszłe zaś wiecznym, Paweł zaczyna mowę o zmartwychwstaniu i mówi tak: «Wiemy bowiem, że jeśli nawet ziemski nasz dom tego przybytku zostanie zniszczony, to mamy budowlę od Boga, dom nie rękami uczyniony, lecz wieczny w niebiosach» (2Kor 5, 1). [...]. Dlaczego opłakujesz osobiste nieszczęścia, skoro musisz się poddać całościowemu rozkładowi ciała, a nawet - lepiej - nie tyle ciała, co zniszczalności,

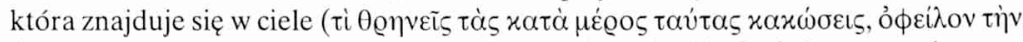

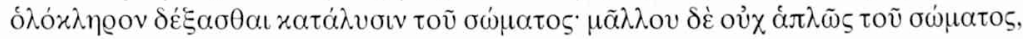

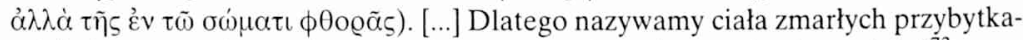

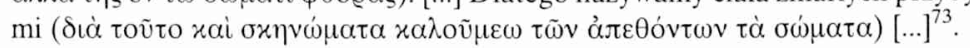

\footnotetext{
68 Expositio in Ps. 48, 5, PG 55, 230AB.

${ }^{69}$ Tamże, 230B.

70 Tamze.

71 Por. De resurrectione mortuorum, CPG 4340, PG 50, 417-432.

72 Por. tamże, 1, PG 50, 417A.

73 Tamże, 6, 426C-427A.
} 
Chryzostom odwołując się do 2Kor 5, 1-2, zwracał też uwagę na filologiczny odcień wypowiedzi apostoła:

„Spójrz jeszcze, jak dokładnego użył on określenia; nie powiedział: «ulegnie zniszczeniu albo rozczłonkowaniu», lecz: «zostanie zniszczone», pokazując, że ono (ciało) ulega rozkładowi, aby zmartwychwstać radośniejszym i o pełniejszym bla-

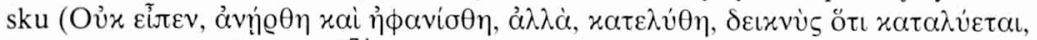

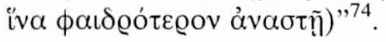

Ponadto u Pawła występuje, jak zauważa Chryzostom, sugestywne rozróżnienie terminów: ciało podlegające rozkładowi funkcjonuje jako przybytek

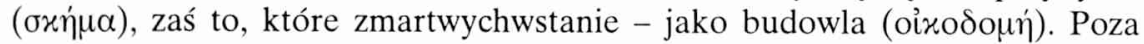
tym dla podkreślenia odmienności i trwałości tego ostatniego, dodaje mu

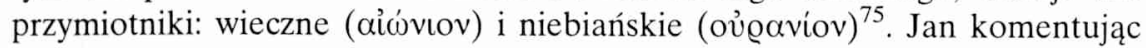
wypowiedź Apostoła z 2Kor 5, 2-4 stwierdzał:

„Znaczenie jego [Pawła] słów jest następujące: nie ciało, jakby on mówił, pragniemy zwlec z siebie, a znikomość; nie ciało, lecz śmierć. Czym innym jest ciało, a czym innym - śmierć. Podobnie czym innym jest ciało, a czym innym znikomość; nie jest ona ciałem. Ciało, co prawda, podlega znikomości, jednak nią nie jest; ciało jest śmiertelne, aczkolwiek nie jest śmiercią. Ciało było dziełem Boga, zaś znikomość i śmierć zostały wprowadzone przez grzech. Tak więc, pragnę, powiada [Pawel], zdjąć z siebie cudze, nie swoje; cudzym zaś nie jest ciało, lecz znikomość. $\mathrm{Z}$ tego też powodu mówi: «ponieważ nie chcemy być zewleczeni», to jest [pozbawieni] ciała, «lecz przyobleczeni» w ciało niezniszczalne. [...] Ciało w samej rzeczy jest czymś uciążliwym i szorstkim, lecz nie ze swej natury, ale z powodu przyłączonej do niego

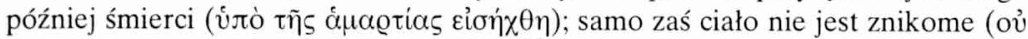
$\phi \theta$ o@à $\delta \dot{\varepsilon}$ tò $\sigma \tilde{\omega} \mu \alpha)$, lecz niezniszczalne" ${ }^{, 76}$.

Dogmatyczny wykład Chryzostoma miał na celu ukazanie słuchaczom prawdziwej natury ludzkiego ciała; bez zrozumienia tego zagadnienia, nauka o zmartwychwstaniu mogła się dla nich wydawać czymś obcym lub wręcz absurdalnym. Duszpasterz kontynuował więc dalej:

„Śmierć w istocie nie jest czymś innym, jak zupełnym unicestwieniem rozkładu, dlatego że śmierć powoduje rozpad nie tyle ciała, ile jego znikomości (ó үà@

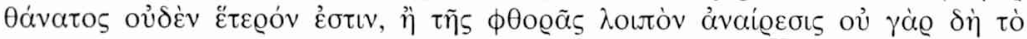

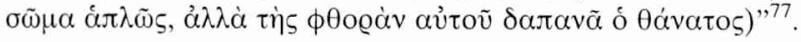

\footnotetext{
74 Tamże, 6, 427B.

75 Por. tamże, 6, 427B.

76 Tamże, 427C-428AB.

77 Tamze, 7, 429B.
} 
Przedstawione wyżej prawdy posiadały ważną soteriologiczną implikację: „Zaprawdę, jeżeli nie zmartwychwstanie ciało, to nie zmartwychwstanie człowiek, dlatego że człowiek jest nie tylko duszą, lecz duszą i ciałem""78.

Chryzostom prawdy o zmartwychwstaniu doszukiwał się także w samej nazwie cmentarza; już ona powinna uwalniać chrześcijanina od trwogi przed śmiercią:

„Dlatego też samo miejsce nazwano miejscem zaśnięcia ( dział, że ci, którzy odeszli i spoczywają na nim, nie umarli, lecz odpoczywają i śpią

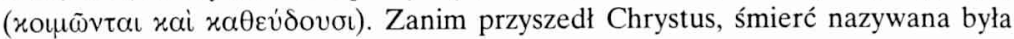
śmiercią [...], lecz kiedy przyszedł Chrystus i umarł za życie świata, to śmierć już nie nazywa się śmiercią, lecz snem i zaśnięciem ( jeśli odprowadzasz [na cmentarz] zmarłego, nie bądź przygnębiony, albowiem nie odprowadzasz go na śmierć, ale do snu. Samej tej nazwy powinno ci wystarczyć do pocieszenia się w nieszczęściu. Wiedz dokąd go [zmarłego] odprowadzasz - na

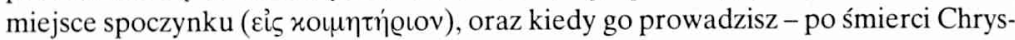
tusa, kiedy więzy śmierci zostały zerwane. W ten sposób zarówno z powodu miejsca, jak i czasu możecie otrzymać wielkie pocieszenie. Słowa te w szczególności dotyczą kobiet, albowiem ich płeć jest szczególnie wrażliwa i skłonna do smutku. Ty zaś posiadasz dostateczne lekarstwo na smutek - nazwę miejsca"79.

Złotoustego niepokoił fakt, że jego wierni wartościowali śmierć nie ze względu na cnotę zmarłego, ale przez wzgląd na towarzyszące śmierci okoliczności:

„Styszałem wielu mówiących: gorzej niż psu zmarło się temu lub tamtemu w obcym kraju, nikogo z krewnych przy nim nie było i nie mogli go pochować w ziemi, tylko nielicznych sąsiadów wezwali do niego, jakoś dzięki składce go ubrali, i w ten sposób został pogrzebany. Dlatego też, żeby [to wszystko] nas nie smuciło, niezbędne jest naprawienie takiego punktu widzenia. Wcale nie to, człowieku, znaczy zakończyć życie gorzej od psa; umrzeć gorzej niż pies oznacza umrzeć w grzechu

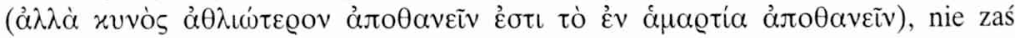
dokonać żywota w obcym kraju. Nie mów mi o tym, że kogoś niosą w pozłacanym łożu, w towarzystwie mieszkańców całego miasta, kogo wysławia naród, na którego narzucono w dużej ilości jedwabne i złote szaty: wszystko to nie oznacza niczego innego, jak tylko propozycję większej uczty dla robaków"80.

Dla Chryzostoma było oczywiste, kto w rzeczywistości umierał śmiercią gorszą, niż pies: „Za nieszczęśliwych uważajmy nie tych, którzy umierają w obcym kraju, lecz umierających w grzechach, wysławiajmy zaś nie tych, którzy odcho-

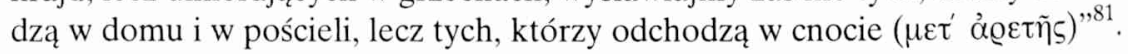

\footnotetext{
78 Tamże, 7, 430A.

79 De coemeterio et de cruce 1, PG 49, 393C-394.

80 De S. Droside martyre 6, PG 50, 691C-692A.

${ }^{81}$ Tamże, 6, 693A.
} 
Podobny wątek znajdziemy również w innej wypowiedziach Antiocheńczyka: ."Śmierć grzesznika jest ciężka» (Ps 33, 22) ${ }^{82}$. [Autor] nazywa śmierć ciężką, kiedy ktoś odchodzi z nieczystym sumieniem, obciążony i miotany świadomością licznych występków"83. Śmierć bowiem nie jest czymś ciężkim dla ludzi żyjących cnotliwie, owszem jest raczej czymś upragnionym ${ }^{84}$.

Wiele cennych informacji o pojmowaniu przez Chryzostoma śmierci zawiera też 4. Homilia na List do Hebrajczyków. Komentując słowa: „I aby wyzwolić wszystkich tych, którzy z powodu lęku przed śmiercią przez całe życie byli w niewoli $(2,15)$ nauczał:

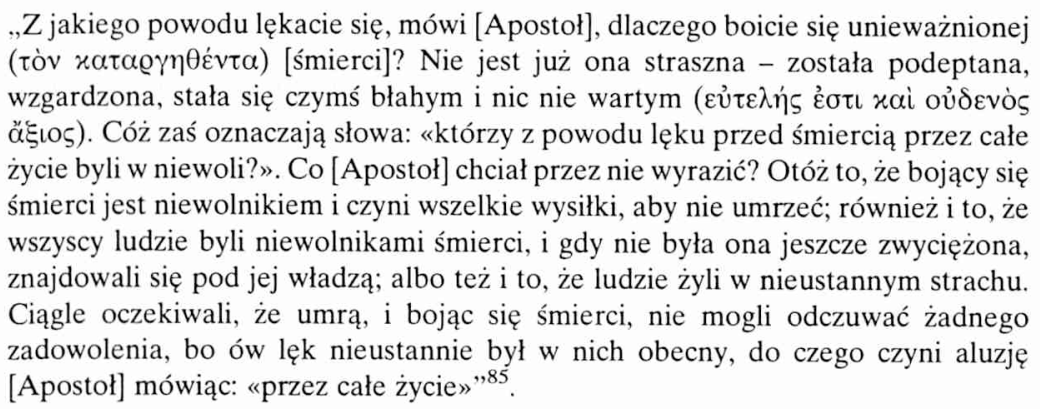

Nieco dalej egzegeta posługuje się bardzo trafnym porównaniem: „Podobnie, jak gdyby ktoś zaczął tuczyć sutym pokarmem skazanego na śmierć więźnia, który ciągle wyczekuje śmierci; tak właśnie śmierć w dawnych czasach [postępowała z ludźmi]" ${ }^{\text {86 }}$. W historii miało miejsce przełomowe wydarzenie Wcielenie Syna Bożego - które zupełnie odmieniło status śmierci względem rodzaju ludzkiego. Stała się ona czymś mało znaczącym, została unieważniona; powinno to implikować właściwą postawę chrześcijan.

Jaką wartość posiada dla chrześcijanina życie doczesne w porównaniu z tym, które będzie miało miejsce po śmierci? Chryzostom spróbowal znaleźć odpowiedź na to pytanie w 3. Homilii na List do Filipian ${ }^{87}$, gdzie komentując

${ }^{82}$ Cytat według Septuaginty. Dla Chryzostoma, który nie znał hebrajskiego, autorytatywnym był tekst Septuaginty. Przy wykładzie Księgi Psalmów sięgal również do przekładów Akwili, Symmacha i nieznanego bliżej tłumacza, zawartych w Heksapli Orygenesa. Natomiast przy egzegezie Księgi Rodzaju bardzo często korzystał z popularnego wówczas w Syrii tekstu - tzw. Biblii Lucjana z Antiochii.

${ }^{83}$ Expositio in Ps. 110, 2, PG 55, 281B.

${ }^{84}$ Por. tamże.

85 In Epistolam ad Hebraeos hom. 4, 4, PG 63, 41C.

86 Tamże, 42A.

87 W Homilii 3. na List do Filipian znajdujemy ważne świadectwo Chryzostoma potwierdzające funkcjonowanie w jego czasach praktyki liturgicznych modlitw w intencji zmarłych. Autor homilii mówi również o apostolskim pochodzeniu tej tradycji. Por. In Epistolam ad Philippenses hom. 3, 4, PG 62, 204B. 
Pawłową wypowiedź (Flp 1, 23-24), nawiązywał do chrześcijańskiego pojmowania śmierci:

„Dobrze, powiada, «odejść, a być z Chrystusem», śmierć bowiem jest czymś obo-

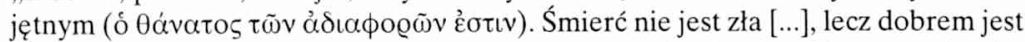
być po śmierci z Chrystusem. [...]. Powinniśmy smucić się nie tylko po umierających, a radować się nie tylko z powodu żyjących. Jakże to? Powinniśmy płakać nad grzesznikami nie tylko umierającymi, ale i żyjącymi. Radować się zaś z powodu nie tylko tych sprawiedliwych, którzy żyją, ale i tych, którzy zmarli. Pierwsi bowiem już za życia umarli, a ci drudzy i po śmierci żyją. [...] Tak więc będziemy opłakiwać

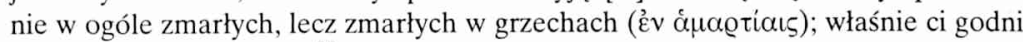
są płaczu, lamentu i łez"88.

Chryzostom pragnął swych słuchaczy uwrażliwić na obecność innego rodzaju śmierci - śmierci duchowej, która w eschatologicznej perspektywie posiadać może bardziej zgubne konsekwencje niż śmierć fizyczna.

Interesujący fragment dotyczący chrześcijańskiego pojmowania śmierci znajduje się również w Homiliach na Dzieje Apostolskie. Pretekstu do rozważań na ten temat, dostarczył Chryzostomowi opis wskrzeszenia Tabity przez Piotra (Dz 9, 36-43):

„Posłuchajcie mnie, proszę, że również nad obecnie zmarłymi (દ̉v toĩs vũv

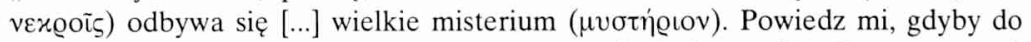
nas [tu] siedzących król wysłał kogoś, by zaprosić do [swego] królestwa, to czyż należałoby [wtedy] płakać i lamentować? [...].Czyż nie wiesz, jaka tajemnica ma miejsce [w związku ze śmiercią], jakże jest przejmująca drżeniem i straszna, lecz

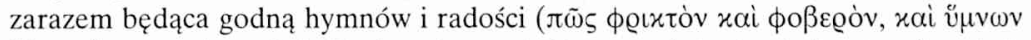

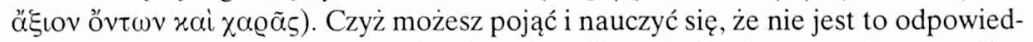

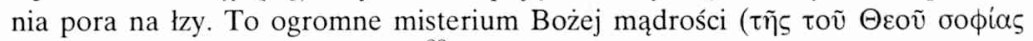

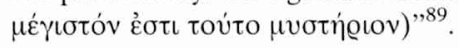

O zaszczepienie wśród wiernych takiego właśnie stosunku do śmierci starał się św. Jan Chryzostom w trakcie całej swej trudnej duszpasterskiej działalności. Dogmatyczna ignorancja wiernych szkodziła jednak nie tylko im samym: Chryzostoma martwił fakt, że chrześcijanie zamiast uświęcać otoczenie swą wypływającą $z$ wiary postawą, nieśli niekiedy zgorszenie podważające autentyczność ich przekonań:

„Jeśli [poganin] zobaczy, że [chrześcijanin] drży przed śmiercią, to jak przyjmie nasze słowa o nieśmiertelności.[...]. My, doprawdy my, jesteśmy winni tego, że poganie pozostają w swej błędnej nauce. Swoje nauczanie dawno już oni osądzili, na nasze zaś patrzą z szacunkiem; lecz nasze życie powstrzymuje ich przed nawróceniem. Łatwo jest uprawiać mądrość jedynie w słowach - wielu z nich (pogan) również tak czyniło; lecz oni potrzebują świadectwa ze strony czynów"90.

${ }^{88}$ In Epistolam ad Philippenses hom. 3, 3-4, PG 62, 202C-203A.

89 In Acta Apostolorum hom. 21, 3-4, PG 60, 168B.

${ }^{90}$ In Ioannem hom. 72, 4, PG 59, 394C. 
2. Starożytne zwyczaje pogrzebowe. Zagadnieniu pogrzebowych obyczajów nadawał Chryzostom jeszcze większe znaczenie, niż walce z niegodnymi chrześcijańskiego imienia obrzędami weselnymi. Jest to zrozumiałe z tego względu, że nadmierny smutek i zwątpienie, towarzyszące śmierci drogiej sercu osoby, mogły zagrozić samemu fundamentowi wiary oraz burzyć misyjne oddziaływanie Kościoła. Na stosunek chrześcijan do śmierci oraz samego sposobu organizowania pogrzebu przemożny wpływ wywierało dziedzictwo pogańskich tradycji. Ludziom obracającym się w środowisku wciąż żywych helleńskich obyczajów, radosna prawda o zmartwychwstaniu wydawała się czymś wręcz nierealnym. Wierni Chryzostoma często nie potrafili zrozumieć pretensji swego duszpasterza, który zarzucał im niedojrzałą postawę w obliczu śmierci kogoś z bliskich. Warto zatem przyjrzeć się bliżej jego swoistej konfrontacji z poglądami ówczesnych chrześcijan.

Duszpasterska troska Chryzostoma o nadanie pogrzebowym zwyczajom wiernych bardziej chrześcijańskiego charakteru oddziaływała na dwóch płaszczyznach: po pierwsze starał się on wykorzenić nieadekwatną wobec nauki o zmartwychwstaniu nadmierną rozpacz po zmarłych, po drugie zwalczał niezgodną z przekazem Ewangelii wystawność pogrzebów.

Zajmijmy się najpierw pierwszym zagadnieniem. Wierni Jana nawet w Biblii potrafili szukać pretekstu do wytłumaczenia swego postępowania. W obronie praktykowanej przez siebie żałoby powoływali się na postawę Józefa, który obchodził żałobę przez siedem dni po śmierci swego ojca Jakuba $(\mathrm{Rdz} 50,10)$. Chryzostom przestrzegał ich przed zbyt naiwną postawą względem takiej interpretacji świętego tekstu:

„Ty zaś, umiłowany, słysząc o tym, pozostań uważny, zdaj sobie sprawę z czasów, w których to wszystko się działo, i nie poddawaj Józefa żadnemu osądzeniu. Wtedy nie były jeszcze złamane wrota piekła, nie były zerwane więzy śmierci, a śmierć nie

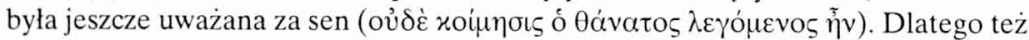
ludzie postępowali w ten sposób [jak Józef], bojąc się śmierci. Teraz zaś, dzięki łasce Bożej, śmierć stała się snem, koniec życia zaśnięciem, obecnie mamy wielką pewność odnośnie zmartwychwstania tak, że przechodząc od życia do życia chlubimy się i weselimy"

Jan wskazuje na kontekst uzasadniający żałobę patriarchy: żył on przecież przed Wcieleniem, teraz natomiast rzeczywistość uległa tak daleko idącej zmianie, że nie da się do niej zastosować argumentu zaczerpniętego z Księgi Rodzaju.

Warto wspomnieć, jaka atmosfera mogła panować na współczesnych Chryzostomowi chrześcijańskich pogrzebach. W jakim stanie emocjonalnym byli krewni zmarłego? Czy w uroczystościach pogrzebowych uczestniczyła tylko najbliższa rodzina?

91 In Genesim hom. 67, 4, 577B. 
„Lecz przychodzi mi ciężko westchnąć [na myśl], dokąd wzniósł nas Chrystus, a dokąd strącamy samych siebie. Gdy wyobrażę sobie rozchodzące się po rynku lamenty, szlochy, które bywają w związku z rozstającymi się z życiem, jęki i pozostałe nieprzyzwoitości, to - uwierzcie mi - wstydzę się wobec pogan ( ${ }^{\prime \prime E} \lambda_{\lambda} \lambda_{\eta}$ a $_{5}$ ), Żydów i heretyków, którzy obserwują to i jawnie śmieją się z nas z tego powodu. Cokolwiek mówiłbym po tym wszystkim o zmartwychwstaniu, słowa moje będą jedynie daremnymi rozważaniami. Dlaczego? Dlatego, że poganie zwracają uwagę nie na to, co ja mówię, lecz na to, co czynione jest przez was. Wówczas mówią: czy ktokolwiek z nich będzie w stanie pogardzać śmiercią, jeśli nie jest w stanie znieść śmierci kogoś innego? Wspaniale mówi Paweł, wspaniale i w sposób godny niebios i filantropii Bożej. Cóż więc on mówi? «I wyzwoli tych, którzy z powodu lęku przed śmiercią przez całe życie byli w niewoli» (Hbr 2, 15), lecz wy nie dopuszczacie do siebie tej wiary, obalając ją swoimi czynami, chociaż Bóg stosuje liczne środki ku temu, żeby zniszczyć wasz niegodziwy zwyczaj [rozpaczania po zmarłych - przyp.

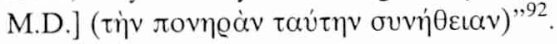

Jak zauważa Chryzostom, ogromna rozpacz chrześcijan po stracie bliskiej osoby, wystawiała na wielką próbę autentyczność nauki o zmartwychwstaniu. Groźby Chryzostoma wymierzone w niegodne zachowanie się chrześcijan brzmiały bardzo realistycznie, zwłaszcza, jeśli weźmie się pod uwagę pewną znaczącą okoliczność:

„Jeśli kogoś z was dotknie ciężka śmierć - nazywam ją ciężką nie przez wzgląd na jej istotę, bo śmierć nie jest już ciężka i wcale nie różni się od snu, lecz nazywam ja ciężką w stosunku do naszych uczuć - jeśli ona się zdarzy i ktokolwiek [z was]

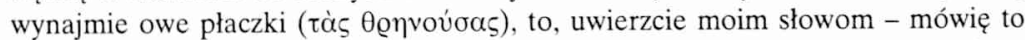
nie inaczej, ale tak, jak powinno być, a kto chce, niech się gniewa - odłączę takiego

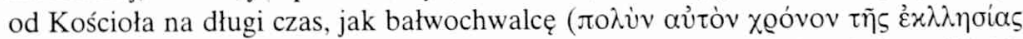

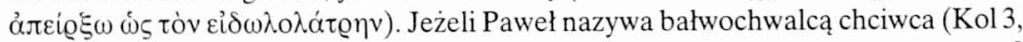
5), to tym bardziej można w ten sposób nazwać tego, który dokonuje nad [zmarlym] wiernym czegoś, co jest właściwe bałwochwalcom. W jakim celu, powiedz mi, zapraszasz [na pogrzebowe uroczystości] prezbiterów i śpiewaków [kościelnych]

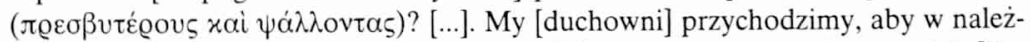
ny sposób rozprawiać o zmartwychwstaniu [...], ty zaś przyprowadzasz takich [domyślnie: płaczących - przyp. M.D.], którzy niweczą nasze działania [...]"93.

Co mógł mieć na myśli Chryzostom, przedstawiając tak ciężkie zarzuty? Otóż, jego zdaniem, owi ludzie uczestniczący w pogrzebowej procesji publicznie ( $(\dot{\pi} \pi$ '

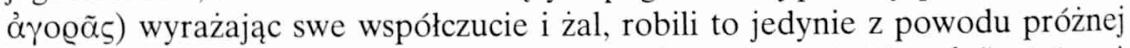

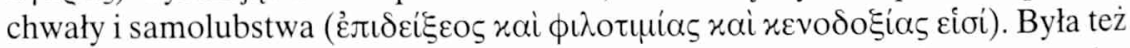
liczna grupa zebranych tam ludzi, którzy trudnili się tym procederem zawodo-

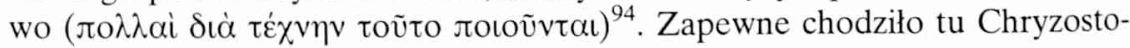

92 In Epistolam ad Hebraeos hom. 4, 4-5, PG 63, 42C-43A.

93 Tamże, 5, PG 63, 44AB.

94 Por. In Epistolam ad Philippenses hom. 3, 4, PG 62, $203 \mathrm{~B}$. 
mowi o najemne płaczki, których obecność, szczególnie na pogrzebach bogatych ludzi, była czymś powszechnym. Drażniło go szczególnie zachowanie się kobiet:

„Nic dziwnego, jeśli postępują w ten sposób świeckie kobiety, chociaż i to jest

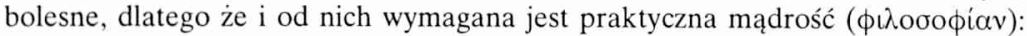
«Nie chcemy zaś, bracia, mówi Paweł, «abyście nie wiedzieli o zasypiających, abyście się nie smucili, jak ci pozostali, nie mający nadziei» (1Tes 4,13). Pisał to [Paweł - przyp. M.D.] nie [tylko] do mnichów i do tych, którzy poświęcili się wieczystemu dziewictwu, lecz i do świeckich kobiet, które zawarły małżeństwo, a także do świeckich mężczyzn"

Sytuacja była jeszcze bardziej bulwersująca, kiedy Jan widział tego rodzaju zachowanie u chrześcijan:

„Zresztą to [o czym wyżej była mowa - przyp. M.D.] nie jest jeszcze takie przykre; ale jeśli ktokolwiek, kobieta albo mężczyzna, przyznający, że ukrzyżowali się dla

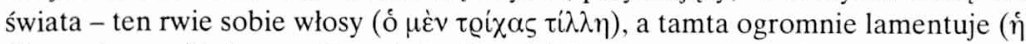
$\delta \varepsilon \dot{~}$ $\omega x u ̛ n ~ \mu \varepsilon \gamma \alpha \dot{\lambda} \lambda \alpha)$ - to cóż może być bardziej gorszące od tego? Uwierzcie moim słowom, że gdyby postępować, tak jak należy, to należałoby takich ludzi odłączyć

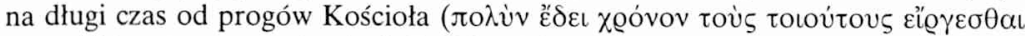

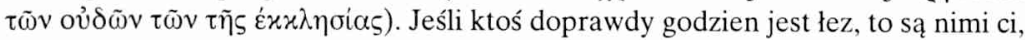
którzy wciąż boją się i drżą przed śmiercią, którzy nie wierzą w zmartwychwstanie. Ale, powiesz, to nie prawda, że nie wierzę w zmartwychwstanie, ja naśladuję

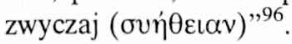

Wielki kaznodzieja nie mógł pozostać obojętny wobec charakteru pogrzebowych procesji. Godne napiętnowania było szczególnie zachowanie się tych chrześcijan, którzy w akcie rozpaczy wyrywali sobie włosy i rozdrapywali policzki. Wśród niektórych wiernych pogańskie obyczaje były jeszcze na tyle żywotne, że nie zapominali o wynajęciu na pogrzeb całego chóru płaczek. Zwyczaj ten rozpowszechniony był szczególnie w bogatym Konstantynopo$\mathrm{lu}^{97}$. O wielkości związanego $\mathrm{z}$ tym problemu świadczyć może fakt, że Chryzostom wynajmowanie płaczek nazywa wprost bałwochwalstwem i grozi odłączeniem od wspólnoty kościelnej tym wiernym, którzy uparcie trzymają się tego zwyczaju.

W jaki sposób ówczesny Kościół starał się objąć swym oddziaływaniem pogrzebowe uroczystości wiernych? Czy można mówić o obecności na nich jakichś typowo chrześcijańskich akcentów? Spójrzmy na ciekawe świadectwo, mówiące o kościelnym aspekcie chrześcijańskiego pogrzebu:

95 In Epistolam ad Hebraeos hom. 4, 5, PG 63, 43B.

96 Tamże, 5, 43B.

97 Por. A. Rain, Sw. Ioann Ztatoust i siemiejnaja żizń jego wremieni. Christianskoje Cztienije, I, S-Pietierburg 1895, 491. 
„Lecz oto, powiedzcie mi, co oznaczają płonące lampy? Czy nie odprowadzamy zmarłych, jak [duchowych] atletów ( hymny? Czyż nie wychwalamy Boga, nie dziękujemy Mu, że na koniec uwieńczył tego, który odszedł, wyzwolił od trudów, wyswobodził od strachu i przyjął go do siebie? Wszystko to właściwe jest radującym się: «Weseli się kto? Niech śpiewa pieśni», powiada [Apostoł] (Jk 5,13). Czyż nie w tym celu są hymny, nie w tym celu psalmodie ( $\psi \alpha \lambda \mu \omega \delta i \alpha u)$ ? Poganin jednak nie zwraca uwagi na to. Nie pokazuj mi powiada on - tego, kto szczyci się mądrością, nie będąc narażony na nieszczęście ( wielkim ani też godnym podziwu, ale pokaż lepiej tego, kto zachowałby dzielność w obliczu samego nieszczęścia ( uwierzę w zmartwychwstanie" 98 .

Chryzostom mówił o braku zgodności między postawą wiernych a kościelną praktyką. Wszystko to demaskowało wobec pogan światopoglądową niestałość uczestników pogrzebów. W Homilii 4. na List do Hebrajczyków znajdujemy ważne świadectwo liturgicznej praktyki pogrzebowej ówczesnego Kościoła:

„Przypomnij, co śpiewasz w tym czasie [podczas pogrzebu - przyp. M.D.]? «Wróć, duszo moja, do spokoju swego, bo Pan był dobry dla ciebie» (Ps 116, 7); i jeszcze: «Nie ulęknę się zła, albowiem Ty jesteś ze mną» (Ps 23, 4); i jeszcze: «Ty jesteś ucieczka moją i strzeżesz mnie od ucisku» (Ps 31, 7). Zastanów się, co znaczą te psalmy. Lecz ty nie zważasz na nie, lecz pijany jesteś z powodu żałoby ( $\dot{\alpha} \lambda \lambda \dot{\alpha}$

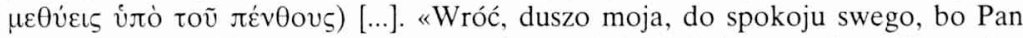
był dobry dla ciebie» - mówisz, a sam płaczesz? Czyż nie jest to udawanie, czyż to nie hipokryzja? Jeśli faktycznie wierzysz w to, co mówisz [w psalmach], to na próżno płaczesz; jeśli zaś czynisz obłudę, jesteś dwulicowy i uważasz [śpiewane teksty] za baśnie, to po co w ogóle je śpiewasz? [...]. Dlaczego nie wypędzasz śpiewających? [...] Lękam się bardzo, żeby w ten sposób nie wkradła się do Kościoła jakaś ciężka choroba" $"$.

Pochodzące od Jana świadectwa wskazują jednoznacznie na istnienie w tamtym okresie uformowanej już kościelnej praktyki, regulującej w zaaprobowany przez Kościół sposób przebiegu chrześcijańskiego pogrzebu.

Czy zatem Chryzostom zabraniał w ogóle wyrażania żalu po śmierci kogoś bliskiego? Owszem, pozwalał płakać jedynie po tych, którzy umierali w grzechach. Dlaczego właśnie po nich? Albowiem w piekle nie można już odnieść

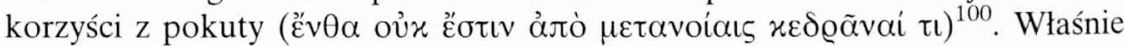
z powodu śmierci takich ludzi pozwalał płakać, ale też bez naruszania granicy

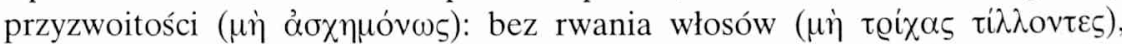

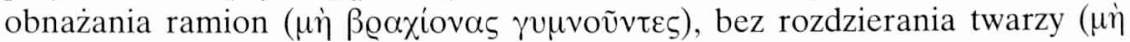

\footnotetext{
98 In Epistolam ad Hebraeos hom. 4, 5, PG 63, 43A.

99 Tamże.

100 In Epistolam ad Philippenses hom. 3, 4, PG 62, 203B.
} 


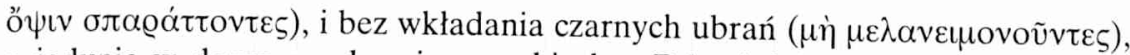
a jedynie w duszy przelewając gorzkie łzy. Również bez uczestnictwa w tej pogrzebowej imprezie ( $\tau \tilde{\eta} \varsigma \pi о \mu \pi \tilde{\eta} \varsigma)$ można gorzko płakać, nie zaś jedynie się

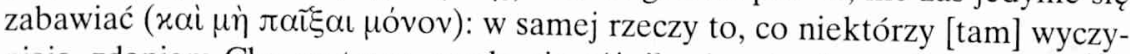
niają, zdaniem Chryzostoma, wcale nie różniło się od zabawy ( $\gamma \iota v o ́ \mu \varepsilon v \alpha){ }^{101}$. Taka postawa autora homilii wyrastała z jego poglądów odnośnie śmierci oraz wolitywnego udziału człowieka w procesie zbawienia; prawdziwie nieszczęśliwy i godny łez był ten, który nie chciał skorzystać z Bożego zaproszenia do osobowego uczestnictwa w zbawczym planie.

Jan zdawał sobie sprawę z tego, że jego wypowiedzi o ówczesnych zwyczajach pogrzebowych mogą wywołać u słuchaczy mieszane uczucia:

„Nie to [postępowanie według moich wskazówek] jest warte śmiechu, lecz to, co czynimy teraz, kiedy płaczemy, szlochamy i jakby grzebiemy siebie razem z umarłymi. Oto co zasługuje na śmiech i kary, cnotę zaś stanowi wszystko to [o czym wam mówiłem - przyp. M.D.]"102.

W innym miejscu, w kontekście krytyki ówczesnych pogrzebowych zwyczajów, broniąc się przed zarzutami z powodu podejrzeń o zarozumiałość, pisał:

„Chociaż jesteśmy mało znaczący, znikomi i godni pogardy, bo rzeczywiście takimi jesteśmy, to nie dla siebie egzekwujemy [od was właściwy sposób postępowania przyp. M.D.], to nie wlasnemu gniewowi dajemy zadowolenie, lecz troszczymy się o wasze zbawienie" ${ }^{\prime 103}$.

Stojąc przed dylematem: czy lepiej jest podobać się Bogu, czy też schlebiać ludziom, Chryzostom nie miał nawet cienia wątpliwości: „Lepiej, żebym był uważany przez was za srogiego, surowego i pysznego, niż [pozwolić] wam czynić to, co nie podoba się Bogu"104.

W kontekście zwyczajów pogrzebowych Chryzostom rozpatrywał również kwestię stosunku chrześcijan do dóbr materialnych. Wynikało to $\mathrm{z}$ faktu, że wielu bogatych wiernych było chowanych z nadmiernym przepychem, a to już, jak wiadomo, nie mogło ujść uszczypliwym uwagom Jana. Nie mógł przeboleć, że namiętność gromadzenia i posiadania bogactw jest aż tak wielka, że nie opuszcza pewnych ludzi nawet po ich śmierci ${ }^{105}$. W trakcie swej duszpasterskiej działalności zmagał się również z popularnym wówczas zwyczajem wznoszenia bardzo okazałych grobowców, które miały zapewnić trwały ślad oraz długą pamięć po zmarłym:

\footnotetext{
101 Por. tamże, 203B.

102 In Ioannem hom. 85, 6, PG 59, 466C.

${ }^{103}$ In Epistolam ad Hebraeos hom. 4, 6, PG 63, 45B.

104 Tamże, 6, 46C.

105 Por. De Anna sermo 5, 5, PG 54, 675-676A.
} 
„Cóż może być gorszego od takiej głupoty (

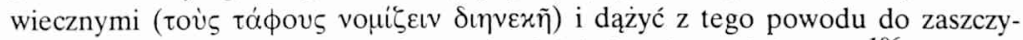
tów. Wielu wznosi bowiem grobowce bardziej okazalsze od domów"106.

Zdaniem Jana, tego typu ludzie nie posiadają żadnej nadziei na przyszłe życie $^{107}$. Komentując zaś słowa Ps 48, 13: „Człowiek w czci będący nie gromadził, zszedł do poziomu zwierząt domowych i upodobnił się do nich" ${ }^{108}$, Chryzostom mówił o ludzkiej trosce dotyczącej budowy wspaniałych grobowców. Zajął się przy tym próbą udzielenia odpowiedzi na pytanie dotyczące istoty człowieczeństwa:

„Tu, zdaje mi się, prorok ubolewa nad tym, że człowiek - istota rozumna (

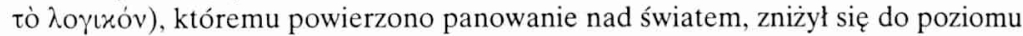
nierozumnych stworzeń, daremnie się trudząc buduje przeciwko swemu zbawieniu, zajmuje się próżną chwałą, oddaje się chciwości, bez końca się trudzi. Dostojeństwo człowieka zawiera się w cnocie ( przewidywaniu przyszłości ( czynić wszystko dla tego [przyszłego] życia i pogardzać obecnym. Życie nierozumnych stworzeń ograniczone jest doczesnym funkcjonowaniem, a nasze podąża ku drugiemu - lepszemu życiu, które nie ma końca" ${ }^{109}$.

Bogaczowi nie pomoże wspaniały grobowiec, bowiem sens funkcjonowania człowieka znacznie wykracza poza granice widzialnego świata. Osoba, która zapomina o Bożym zaproszeniu do życia wiecznego, niszczy własne człowieczeństwo, umiera jeszcze za życia. Jan mówiąc o dwóch rodzajach śmierci: fizycznej i duchowej, przestrzegał przed zgubnymi konsekwencjami tej ostatniej, albowiem jej przyczyną jest wolna wola człowieka. Człowiek żyjący w grzechach umiera już na dhugo przed śmiercią fizyczną ${ }^{110}$.

W bogatych pogrzebach dostrzegał Chryzostom dobra zagrabione ubogim i bezsensownie marnotrawione. Zamiast drogocennych szat zmarłego, które stanowić będą jedynie pokarm robaków, sugeruje, aby przez wzgląd na przyzwoitość dać mu jedynie skromne okrycie:

„Mówię tak nie dlatego, jakobym zabraniał troszczyć się o zmarłych, lecz dlatego, abyście czynili to $\mathrm{z}$ umiarem, jedynie okrywali ciało [zmarłego] i nie składali go do ziemi nagim. Jeżeli żywym nie wypada mieć [z ubrania] niczego więcej, jak tylko przykrycie ciała, to tym bardziej zmarłym [...]. Dopóki żyjemy, potrzebna nam jest odzież ze względu na chłód oraz skromność; skoro zaś umarliśmy - nie ma już u nas takich potrzeb, a jedynie takie, żeby ciało nie leżało nagim; stąd potrzeba nam

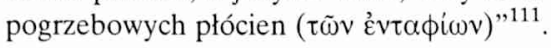

\footnotetext{
106 Expositio in Ps. 48, 6, PG 55, 231 A.

107 Por. tamże.

108 Według Septuaginty.

109 Expositio in Ps. 48, 6, PG 55, 232AB.

${ }^{110}$ Por. tamże, 9, 235C-236.

111 In Ioannem hom. 85, 6, PG 59, 466C.
} 
Właściwy stosunek chrześcijan do śmierci stanowi najlepsze misyjne świadectwo autentyczności ich wiary:

\begin{abstract}
„W takim przypadku wszyscy nas pochwalą, przyjrzą się mocy Chrystusowej i powiedzą: o, jakże wielka jest potęga Ukrzyżowanego! Przekonał on śmiertelnych i podlegających rozkładowi ( $\phi \theta \varepsilon £ \varrho o \mu \varepsilon ́ v o v \varsigma)$, że śmierć nie jest śmiercią, i oto oni postępują tak, jakby w ogóle nie umierali, lecz przemieszczali się do lepszej krainy. [Chrystus] przekonał ich, że to znikome i przemijające ciało przyoblecze się w szatę nieporównywalnie wspanialszą od jedwabnych i przetykanych złotem ubiorów - przyoblecze się w niezniszczalność; i dlatego [chrześcijanie] nie troszczą się zbytnio o pogrzeby, lecz za najlepszą pogrzebową ozdobę uważają cnotliwe życie. Tak wszyscy będą o nas mówić, kiedy ujrzą nas praktykujących cnotę

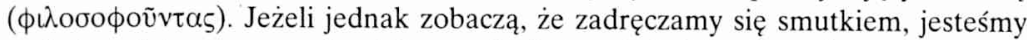

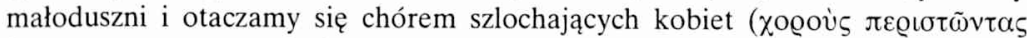

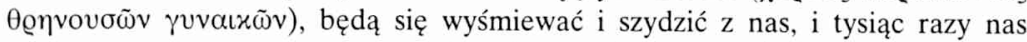
osądzą, czyniąc wyrzuty $z$ powodu nierozsądnej straty i daremnego trudu. I w rzeczywistości słyszymy, że z tego powodu wszyscy nas osądzają, i mają w tym całkowitą rację"112.
\end{abstract}

Gdzie w takim razie duszpasterz radzi szukać godnych przykładów sprawowania prawdziwie chrześcijańskiego pogrzebu? Za warty naśladowania przykład Chryzostom wskazywał chrześcijańskich ascetów:
„Nie słychać tam nigdy lamentów ani zawodzeń; duch wolny jest od takich nie- przyjemności, wolny od takiego krzyku. I tam wprawdzie umierają, bo ciałem nie są nieśmiertelni, ale śmierci nie uważają za koniec. Zmarłych wynoszą wśród hymnów i nazywają to nie pogrzebem, lecz uroczystym odprowadzeniem, czy wysłaniem naprzód ( oznajmią, że ten a ten skończył, panuje wielkie wesele, wielka radość, i nikt nawet nie śmie powiedzieć, że ten a ten skończył, lecz że doszedł do doskonałości

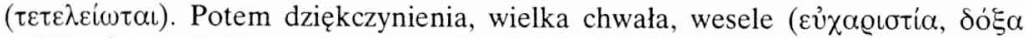 $\pi 0 \lambda \lambda \dot{\eta} \varepsilon \dot{\phi} \phi \varrho o \sigma u ́ v \eta)$; Każdy się modli o to, by sam miał taki koniec i tak wyszedł z tych zapasów, aby znalazł kres trudu i walk oraz zobaczył Chrystusa"113.

Przekazanie wiernym tak dojrzałego stosunku do śmierci stanowiło znaczący nurt duszpasterskiego trudu Jana Chryzostoma. Aby zrozumieć obawy duszpasterza, należy pamiętać, że w tym czasie nawracanie mieszkańców Cesarstwa na chrześcijańską wiarę było jeszcze wciąż dalekie od zakończenia, a poganie, szczególnie ci wykształceni, łatwo dostrzegali rozbieżność wiary i życia chrześcijan. Pogrzeb nie mógł służyć za podkład gorszących obyczajów i ceremonii, nie mających nic wspólnego z zaszczytnymi ideałami Ewangelii.

112 Tamże, 466C-467A.

113 In Epistolam I ad Timotheum hom. 14, 5, PG 62, 577BC, thum. T. Sinko: Homilie na listy pasterskie i na list do Filemona, Kraków 1947, 152-153. 
Zmagania Chryzostoma o nadanie chrześcijańskiego wizerunku uroczystościom weselnym i pogrzebowym, pozwalają naszkicować interesujący wizerunek moralności współczesnego wielkiemu kaznodziei społeczeństwa. Umożliwiają też zrozumienie skali jego duszpasterskiego wysiłku i odpowiedzialności wobec trudu przyjętego powołania. Służbę duszpasterską pojmował on, podobnie jak św. Paweł, jako zaproszenie wiernych do nieprzerwanego, rzeczywistego ,życia w Chrystusie.” Stąd z jednej strony ukazywał możliwość jego realizacji drogą prozaicznych codziennych czynności, z drugiej zaś bezlitośnie demaskował niewłaściwe, dysharmonizujące z przesłaniem Ewangelii obyczaje. Jego zasługa polegała na przypomnieniu dla przepojonego nominalizmem i bylejakością „,cesarskiego” chrześcijaństwa, że prawdy wiary zyskują swój autentyzm dopiero na płaszczyznach zwykłego, codziennego życia.

Jakie były przyczyny niewielkiej skuteczności duszpasterskiego oddziaływania tak przecież nietuzinkowej osoby, jak Chryzostom? Po pierwsze, wydaje się, że obie strony, kaznodzieja i słuchacze, nie bardzo się rozumieli. Jan nie potrafil, a może raczej nie chciał zdać sobie sprawy z tego, że chrystianizm większości jego słuchaczy stanowił jeszcze jedynie zewnętrzne okrycie, w dodatku niedbale uszyte i założone w pośpiechu. W takim wypadku zasięg oddziaływania wyznawanej wiary ograniczał się zazwyczaj do określonego czasu i miejsca; stąd zbyt ambitne próby wykreowania wiernych na przykładnych chrześcijan, w większości przypadków z góry były skazane na klęskę. Po drugie, bezkompromisowość Chryzostoma pozbawiała go zbyt często taktu i szeroko pojmowanej wyobraźni. Cechowała go stuprocentowa prawość, a w pełnieniu swych obowiązków odznaczal się nieprzejednaniem ludzi prawych ${ }^{114}$; to wszystko miało z kolei wpływ na zdolność percepcji u jego słuchaczy. Duszpasterz nad wyraz często był postrzegany jako staromodny gbur, który poczucie dobrze wypełnionego obowiązku cenił znacznie wyżej od potrzeby rozumnego dialogu ze słuchaczami. Po trzecie wreszcie, ludzie Kościoła, a Chryzostom nie był tu bynajmniej wyjątkiem, bagatelizowali aksjologiczną stronę przyzwyczajenia ówczesnych chrześcijan do praktykowania helleńskich obyczajów. Coś, co początkowo wydawało się czymś błahym i łatwym do usunięcia, ostatecznie okazywało się barierą nie do pokonania.

Rozdźwięk więc między nauką Kościoła a postępowaniem wiernych był szczególnie widoczny w ich postawie wobec zawierania małżeństwa oraz w stosunku do śmierci. Sam zamysł duszpasterskiego trudu Chryzostoma był nad wyraz chwalebny; bez podjęcia prób wkomponowania chrześcijańskich ideałów w te jedne z najważniejszych przejawów ludzkiej aktywności, Kościół

114 Por. A. Hamman, Portrety Ojców Kościola. Praktyczny przewodnik po patrologii, Warszawa $1979,166-167$. 
nieuchronnie skazałby się na utratę swej ewangelicznej autentyczności i misyjności. Z drugiej strony mała skuteczność duszpasterskiego trudu Chryzostoma wskazywała na ograniczony zasięg oddziaływania ówczesnego Kościoła oraz przewagę niezależności obyczajowego życia człowieka nad próbami jego ukościelnienia.

\section{CHRISTLICHE HOCHZEITS- UND BEGRABUNGSSITTEN IM LICHT DER SEELSORGERISCHEN TÄTIGKEIT VON JOHANNES CHRYSOSTOMUS}

\section{(Zusammenfassung)}

In seiner seelsorgerischen Arbeit sterbte Johannes Chrysostomus nach der Christianisierung den allen Lebensgebieten. Das mit dem Alltagsleben zusammenhanglose Christentum war für ihn ein Schein, der mit dem Neuen Testament widerschprach. Er war ein Verfechter [ein Verkünder] des Christentums als apostolische Reinlichkeit und Kompromißlosigkeit. In diesem Fall war die Seelsorge ein unaufhörliches Streben nach der Verbindung der allen Lebensäußerungen mit dem Geist des Evangeliums.

Die Evangeliumsverbreitung, sowohl unter den Bewohner von Antiochien, als auch in Konstantinopel, war eine äußerst schwere Aufgabe. Das betraf insbesondere die Frage nach den in der Kultur hineingewachsenen Hochzeits- und Totenfeiern. Auf dieser Ebene wurde in vollem Umfang eine Antithese der beiden Reichen sichtbar: des christlichen und des heidnischen. Es war für Chrysostomus evident, da das auf dem Gebiet des gewöhnlichen, alltäglichen Lebens nicht realisierte Christentum seine Authentizität verliert und seine Fähigkeit der erfolgreichen Missionsführung verpaßt. Nach Chrysostomus profanierte die Hochzeit das Heiligtum der christlichen Ehe. Die Anwesenheit der Spieler, Tänzern in die Hochzeitfeiern bewirkte die Verknüpfungen mit dem Theater, an dem Chrysostomus die Hauptquelle des sittlichen Verfalls unter den Christen fand. Die mit dem Begräbnis verbundene Bräuche schlugen wiederum in einem von den wichtigsten Dogmen des Christentums: in Glauben an der Auferstehung und dem Ewigen Lebens. Was betrifft der Wahrheiten des Glaubens, Chrysostomus fand eine extreme Ignoranz in seinen Gläubigen. Außerdem bemerkte er einen verderblichen Einfluß des falschen Verhältnises der Christen zum Tod auf der Missionsumtreibe der Kirche.

Der Kampf Chrysostomus mit den unwohlen Sitten seiner Gläubigen läßt ein interessantes Bildnis der Moral der damaligen Gesellschaft skizziren. Sie auch ermöglicht ein Verständnis des Mastabs der seelsorgerischen Mühe Chrysostomus und der Verantwortlichkeit für die von ihm aufgenommene Berufung. 